\title{
Effects of land-use change on herbaceous vegetation in a semi-arid Mopaneveld savanna
}

\section{Authors \\ ${ }^{1} \mathrm{~F}$. Siebert (D) \\ ${ }^{1} \mathrm{~N}$. van Staden \\ 1,2D.M. Komape (1) \\ ${ }^{3}$ A.M. Swemmer (1) \\ S.J. Siebert (1)}

\section{Affiliations}

'Unit for Environmental Sciences and Management, North-West University, Private Bag X6001,

Potchefstroom 2520, South Africa.

${ }^{2}$ Nature Conservation, Tshwane University of Technology, Pretoria, South Africa.

${ }^{3}$ SAEON Ndlovu Node, Phalaborwa, South Africa.

\section{Corresponding Author}

Dr F. Siebert,

frances.siebert@nwu.ac.za

\section{Dates}

Submitted: 1 October 2019

Accepted: 7 May 2020

Published: 24 February 2021

\section{How to cite this article:}

Siebert, F., Van Staden, N., Komape D.M., Swemmer, A.M. \& Siebert, S.J., 2021, 'Effects of land-use on herbaceous vegetation in a semi-arid Mopaneveld savanna', Bothalia 51(1), a8. http://dx.doi. org/10.38201/btha.abc.v51.i1.8
Background: Low altitude Mopaneveld savanna in the northeastern parts of South Africa is generally well conserved. However, extensive copper mining, agricultural practices and urbanisation in the Phalaborwa region prompted research on the possible effects of land-use change on plant community diversity and function. Species diversity measures are usually considered adequate to assess disturbance effects to inform conservation efforts and management practices. However, diversity measures based on species level accounts often limit the outcomes of these studies as this approach fails to quantify how disturbances affect ecosystem functioning when community assembly, and not species diversity alone, is altered by land-use change.

Objectives: The aim of this study was to apply both species and functional diversity measures to a data set derived from various land-use types (i.e. areas exposed to strip mining activities, communal farming practices and conservation) in the Phalaborwa region to examine the effects of land-use change on the community ecology of the herbaceous layer.

Results: Land-use change, particularly severe top-soil disturbances through strip mining activities, had a significant filtering effect on all measures of species diversity, though functional evenness was maintained across land-use types.

Conclusion: These results suggest that, despite initial species loss, this particular savanna ecosystem is buffered against anthropogenic disturbances through functional stability. Indicator species analyses, as well as relationships between plant functional types and land-use change, revealed that forb species are largely responsible for ecosystem stability in areas exposed to anthropogenic disturbances.

Keywords: forb, plant functional type, anthropogenic disturbances, ecosystem stability

\section{Introduction}

Global land-use intensification and non-sustainable land-use practices are pushing terrestrial biomes beyond their environmental boundaries (Newbold et al. 2015), resulting in biodiversity losses. Increasing land-use pressure in African savannas has led to significant species loss (e.g. Shackleton 2000; Rutherford, Powrie \& Thompson 2012; Zerbo et al. 2016). Since savannas provide essential ecosystem goods and services to indigenous livelihoods (Shackleton 2000), decreasing species richness and abundances that approach global thresholds (Newbold et al. 2015) should be of great concern in Africa.

Reducing biodiversity loss requires larger protected areas, land-use diversification or active restoration of degraded landscapes (Newbold et al. 2015; Dudley et al. 2018). Protected areas function to counter species loss as they are designed to maintain habitat integrity and species diversity. However, higher species richness is often reported in landscapes outside protected areas 
(Shackleton 2000), often in areas perceived as degraded due to habitat transformation associated with severe anthropogenic pressure. For instance, communal rangelands are generally associated with lower plant cover (Shackleton 2000; Rutherford, Powrie \& Thompson 2012), but species richness, diversity and evenness can either be maintained (Rutherford, Powrie \& Thompson 2012) or enhanced (Shackleton 2000) under high intensity communal grazing. Other studies on grazing effects on plant communities state that species richness and diversity alone seem to have weak responses to increasing grazing pressure (Hanke et al. 2014; Herrero-Jáuregui \& Oesterheld 2018). Further weaknesses in studying disturbance effects on vegetation include a limited understanding of the relationship between diversity patterns and plant functional attributes, especially in African savannas. Linking plant species diversity and abundance patterns to functional trait groups and trait diversity should elucidate the potential vulnerability of African savannas to anthropogenic drivers of ecosystem change and improve our understanding of African savanna ecosystem resilience (Hanke et al. 2014; Osborne et al. 2018).

Relating biodiversity and functional losses to current land-use practices (Botha et al. 2017) should consider the intensity, and more specifically the duration of landuse disturbances, since past effects strongly affect biodiversity patterns and resilience (Shackleton 2000). This study therefore aimed to test land-use change effects on the community ecology of herbaceous vegetation in a semi-arid Mopaneveld savanna, with the specific objectives to (i) consider context-specific disturbance effects, and (ii) compare species- and functional trait responses across land-use types, in this case strip mines, communal land and protected area. Context-specific disturbance effects consider the species pool, and how long and intense the area has been exposed to a particular disturbance.

Land-use practices can be classified into land-use classes (Scholes \& Biggs 2005). Mining sites are included under the urban land-use class, whereas communal areas of varying land-use intensity are considered to represent a degraded land-use class. Protected areas, without any clear, direct anthropogenic disturbances, fall under the protected land-use class. We expected that the herbaceous vegetation in the protected land-use class, which is adapted to natural disturbances such as herbivory, fire and climate variability, will host highest species and functional diversity (Gray et al. 2016). Increased herbaceous species richness in communal rangelands (Shackleton 2000; Rutherford, Powrie \& Thompson 2012) led us to predict highest richness, diversity and evenness (at both species and functional trait levels) in the degraded land-use class. In contrast, we expected lowest species richness, diversity and evenness in the mining sites (i.e. urban land-use class) due to extensive soil disturbances at these sites (Yan, Zhao \& Sun 2013). Herbaceous plant functional types were predicted to represent adaptations to competition (e.g. in the protected, untransformed area), abiotic limitation (e.g. in transformed, mining areas) or periodic biomass destruction (e.g. in the degraded communal areas) (Shackleton 2000; Hillebrand, Bennet \& Cadotte 2008). An improved understanding of the community ecology of herbaceous vegetation across land-use types will indicate how species and their respective functions are affected by land-use changes, and how they can be maintained under increasing land-use pressure and drought (Siebert \& Dreber 2019; Siebert, Klem \& Van Coller 2020; Kellner et al. 2021).

\section{Methods}

\section{Site description}

The study was conducted in the Phalaborwa region $\left(23^{\circ} 56^{\prime} 45.47^{\prime \prime} \mathrm{S}\right.$; $\left.31^{\circ} 08^{\prime} 46.23^{\prime \prime} \mathrm{E}\right)$ of Limpopo, South Africa (Figure 1). The Phalaborwa-Timbavati Mopaneveld is characterised by an undulating, open tree savanna landscape dominated by the leguminous tree Colophospermum mopane (J.Kirk ex Benth.) J.Kirk ex J.Léonard (Mucina \& Rutherford 2006). Semi-arid Mopaneveld vegetation is characterised by a homogenous woody plant structure interspersed with a dynamic herbaceous layer (Siebert, Eckhardt \& Siebert 2010).

The Phalaborwa region is considered a multi-functional landscape with land-uses varying from subsistence and commercial farming, large mining operations and land managed for conservation. Considering the increases in human-induced transformation of Phalaborwa-Timbavati Mopaneveld vegetation through mining operations and human settlements (Mucina \& Rutherford 2006), study sites related to these practices were selected to investigate vegetation responses. Based on the classification of Scholes and Biggs (2005), three land-use classes were sampled, which included urban (i.e. strip mining practices at Pompeye), protected (i.e. untransformed Mopaneveld) and degraded (i.e. communal rangelands and crop fields of Lulekani) (Table 1).

Strip mining is described as surface mining where vegetation, topsoil and rock material located above the targeted seam layer (i.e. quartz-feldspar) is removed (Hustrulid 2013). Two surface mined areas (land-use types) were included for this study and consisted of strips that were mined between 1970 and 1980 (>30 years since impact) and an area mined between 1995 until 2005 (i.e. more recent strips; <15 years since impact). After mining was completed, the overburden was redistributed across the mined landscape, and then shaped. Human intervention was limited and managed as part of a game reserve, which hosts several roaming game species. Vegetation was left to regenerate naturally, 


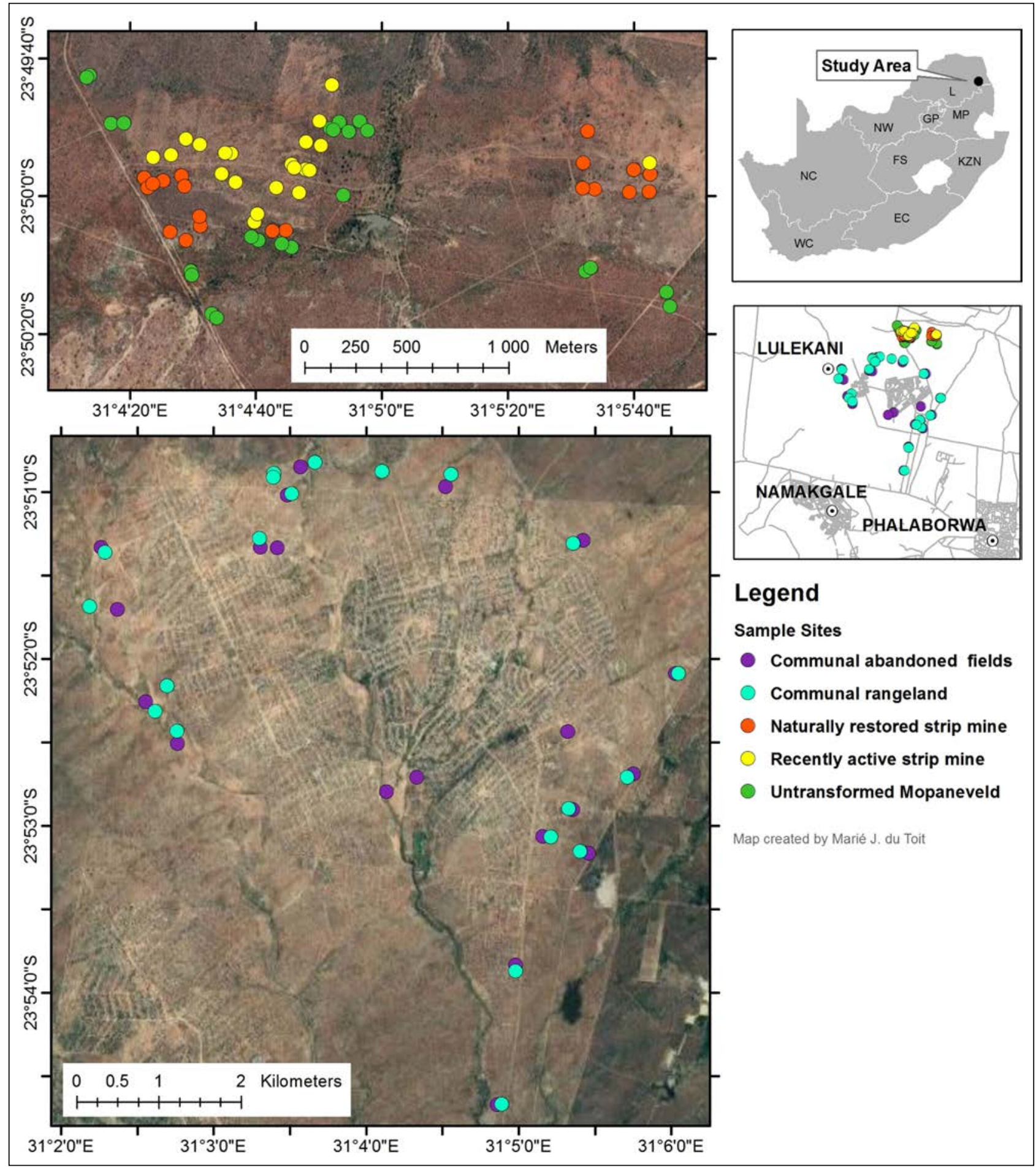

Figure 1. Study area and locality of sampled sites. Strip mines and untransformed Mopaneveld is located at Pompeye (top) and communal areas at Lulekani (bottom).

with the mined area supporting a dense grass sward and bush clumps along drainage lines. Vegetation without considerable soil disturbance or heavy grazing were selected from undisturbed parts of the reserve to serve as a benchmark system, i.e. the untransformed Mopaneveld land-use type (Table 1).

Communal areas were selected in and around the rural communal village of Lulekani, approximately $5 \mathrm{~km}$ west of strip-mined and untransformed sites at Pompeye. This degraded land-use class (Scholes \& Biggs 2005) has a long history of subsistence farming, including small-scale crop fields and communal rangelands. Subsistence croplands were exposed to topsoil disturbance through ploughing, although fields were not cultivated annually. Surveys were conducted in abandoned fields that have lain bare for one or more seasons. These sites were characterised by a dense herbaceous layer of 
Table 1. Summary of study sites, land-use types and the respective land-use classes

\begin{tabular}{|c|c|c|c|}
\hline Study site & Land-use types & $\begin{array}{l}\text { Description of natural and anthropogenic } \\
\text { disturbance types }\end{array}$ & Land-use class \\
\hline \multirow[t]{3}{*}{ Pompeye } & $\begin{array}{l}\text { Naturally restored strip mines (i.e. strip } \\
\text { mining activity }>30 \text { years ago) }\end{array}$ & $\begin{array}{l}\text { Mined between } 1970 \text { and } 1980 \\
\text { Grazing area for game }\end{array}$ & Urban \\
\hline & $\begin{array}{l}\text { Recent strip mine activity area (i.e. strip } \\
\text { mining activity }<15 \text { years ago) }\end{array}$ & $\begin{array}{l}\text { Mined between } 1995 \text { and } 2005 \\
\text { Grazing area for game }\end{array}$ & Urban \\
\hline & Untransformed Mopaneveld & $\begin{array}{l}\text { Managed as a game reserve } \\
\text { Grazing area for game }\end{array}$ & Protected \\
\hline \multirow[t]{2}{*}{ Lulekani } & Communal rangelands & $\begin{array}{l}\text { Grazing area for livestock } \\
\text { Heavily utilised for natural resources }\end{array}$ & Degraded \\
\hline & Communal abandoned fields & $\begin{array}{l}\text { Disturbed by ploughing } \\
\text { Fields not cultivated annually } \\
\text { Grazing area for livestock }\end{array}$ & Degraded \\
\hline
\end{tabular}

forbs and grasses, which were heavily grazed upon by cattle and goats that maintained the herbaceous community in a grazing lawn state (Fox et al. 2015). Shallow erosion gullies were observed. Rangelands were used as grazing areas for livestock and heavily utilised for the harvesting of natural resources, such as firewood, fruit, thatch grass and construction wood (Shackleton 2000). Resprouting trees were a common phenomenon in rangelands, whereas the abandoned fields were characterised by large, solitary specimens of large savanna trees, mostly marula (Sclerocarya birrea (A.Rich.) Hochst. subsp. caffra (Sond.) Kokwaro).

\section{Data collection}

Floristic data were collected from February to March 2013 during the peak growing season and the ideal time during which the majority of species will be observable for diversity studies. Surveys were conducted in randomly placed sites containing pairs of $1 \mathrm{~m}^{2}$ plots situated $50 \mathrm{~m}$ apart. A minimum of 20 plots per landuse were sampled to meet the optimum number for statistical analyses. All herbaceous individuals rooted within each plot were counted and identified to species level, and percentage cover of grasses and forbs (i.e. non-graminoid, dicotyledonous and monocotyledonous herbaceous plants) was visually estimated.

To elucidate potential indirect effects of woody density (in addition to land-use type) on herbaceous composition, woody vegetation was sampled along ten transects of $50 \times 5 \mathrm{~m}$ per land-use type, following the strip transect method (Hill 2005). All trees and shrubs of $>1.5 \mathrm{~m}$ in height within the transect were measured, namely the canopy height, stem diameter at breast height (i.e. $\mathrm{DBH}$ at $\sim 1.4 \mathrm{~m}$ ) and crown diameter. Stem diameter was converted to basal area in $\mathrm{m}^{2} /$ ha.

Species names follow Germishuizen and Meyer (2003). Unknown specimens were identified by the Pretoria
National Herbarium (PRE) and voucher specimens were deposited in the A.P. Goossens Herbarium (PUC) and Skukuza Herbarium (KNP).

\section{Data analysis}

\section{Herbaceous species composition}

To assess land-use effects on herbaceous species composition, the Bray-Curtis similarity measure was selected in a Non-parametric Permutational Multivariate Analysis of Variance (PERMANOVA; permutations = 999; type III sum of squares) design (Anderson \& Walsh 2013). Since rare species may add noise to community assemblage data analyses, species with an abundance value of ten or less individuals were omitted to reduce the number of statistical outliers (Lepš \& Šmilauer 2003). Abundance data were fourth root transformed to furthermore reduce the weighting of abundant species. To assess the significance of clustering among landuse sites, posteriori pairwise comparison of levels of a single factor (i.e. land-use) were conducted (Anderson \& Walsh 2013). Homogeneity of dispersion was tested with PERMDISP (Anderson, Ellingsen \& Clark 2006). PERMDISP tests were conducted using deviations from the centroid with 9999 restricted permutations selected. Land-use type effects on herbaceous species composition were depicted by Non-metric Multidimensional Scaling (NMDS) based on the Bray-Curtis Similarity Index for ordination. PERMANOVA and PERMDISP (using the PERMANOVA PLUS routine) as well as NMDS analyses were performed in PRIMER 6 (2012) with land-use type as fixed effects.

\section{Herbaceous species diversity}

Species richness $(S)$ and diversity index values were calculated in PRIMER 6 (2012) using total species richness per plot. Indices selected for further analyses were 
Margalef's species richness $(d)$, Pielou's evenness $\left(J^{\prime}\right)$ and Simpson Diversity (1- $\kappa$ ). Effects of land-use on richness and diversity were tested by using a hierarchical Linear Mixed Model (LMM) with plots nested within land-use types. Data not normally distributed, were transformed with the natural logarithm $(\operatorname{Ln}(x+1))$. Land-use was set as a fixed factor and plots as the random factor. Type III Sum of Squares was performed to test whether landuse had a significant effect on diversity index values. Significant differences between land-use types were tested through the application of linearly independent pairwise comparisons among estimated marginal means using the Sidak multiple comparisons test. SPSS version 25 (IBM Corp, 2016) was used for LMM analyses.

Pearson's correlations ( $r$ coefficient) were applied to all herbaceous species diversity measures to test for indirect effects of woody density on herbaceous plant diversity and biomass.

\section{Herbaceous indicator species and plant functional analyses}

Indicator species analysis combines the relative abundance and frequency of species among sites (Dufrêne \& Legendre 1997). Species with a high indicator value are therefore considered to be abundant and diagnostic of a specific treatment and/or habitat (Roberts 2019). The Indicator Value index (IndVal) was used to identify herbaceous indicator species per land-use class to improve our understanding of species-specific responses of herbaceous communities to environmental perturbations (Linstädter et al. 2014). Indicator values were calculated using the labdsv package (Dufrêne \& Legendre 1997) in RStudio. Significance levels were set at $p<0.05$.

Plant traits were assigned to each recorded species according to field guides and taxonomic literature (e.g. Germishuizen 1997; Germishuizen \& Meyer 2003; Van Oudtshoorn 2009; JSTOR 2015). Traits were selected to represent tolerance or adaptability of species to anthropogenic and/or natural disturbances (Mori, Farukawa \& Sasaki 2013). A complete species-trait list is provided in the supplementary material (Table S1).

All herbaceous plant species represented by more than ten individuals in at least one of the land-use classes (communal, protected and urban) were considered for functional analyses (Peco et al. 2012). The complete functional trait data matrix consisted of 202 species and seven traits. The trait-species matrix was multiplied with the species-abundance matrix using the MMult function in Microsoft Excel 2007 to produce a matrix from which trait diversity index calculations (richness, evenness and diversity) could be conducted in PRIMER 6 (Hanke et al. 2014). Similar to species diversity analyses, the effect of land-use on trait diversity index values was examined using LMM analysis in SPSS (IBM Corp 2016).
Since life history remains the strongest indicator of disturbance (Pérez-Harguindeguy et al. 2013), effects of underlying important disturbance traits may be weakened when all functional plant groups are analysed collectively (Lavorel et al. 1997). For this reason, we applied Principal Co-ordinate Analysis in PRIMER 6 (2012) of the complete species-trait matrix to test for clustering based on life history, which was confirmed by the separation of annuals and perennials in ordinal space (Figure S1). Furthermore, disturbance responses are often irregular among different herbaceous life forms (Van Coller et al. 2018). To disentangle all the plant functional types (PFTs) from the herbaceous communities in the study area, trait datasets were therefore analysed separately for annuals and perennials, of which each were further subdivided into grasses and forbs to reveal four overall functional groups. The use of binary and categorical data motivated the selection of a modified Gower dissimilarity metric (Botta-Dukát 2005) for hierarchical cluster analysis (PRIMER 6 2012). We applied UPGMA-cluster analyses (Unweighted Pair Group Method with Arithmic Mean) together with a Similarity Profile (SIMPROF) test to identify clusters. SIMPROF is described as an objective method for the identification of significant groupings compared to subjective cut-off levels (Clarke, Somerfield \& Gorley 2008). Groupings of plant functional groups were therefore identified by the cut-off point, indicated by SIMPROF where dashed lines within the dendrogram denoted no significant groupings. Each life history group was analysed separately to identify, describe and discuss the PFTs across land-use types. Plant functional trait (PFT) clusters were identified according to the grouping of plant species based on their trait scores, which revealed PFTs at different hierarchical levels, following the approach of Linstädter et al. (2014). A Principal Component Analysis, using CANOCO 5 software (Šmilauer \& Lepš 2014), was applied to the data to provide a summary of community trait variation and to investigate to what extent the PFTs that were correlated with land-use types.

\section{Results}

\section{Herbaceous species composition}

PERMANOVA results revealed a significant effect of land-use on herbaceous species composition (Pseudo- $F$ $=5.703 ; p<0.001)$, although the two-dimensional visual representation of the ordination (NMDS) showed rather weak clustering of plots according to land-use types (Figure 2). Homogeneity of multivariate dispersion was not significant among the communal land-use types and the protected area $(F=0.662 ; p=0.52)$, which support the significance of clustering of these land-use types. Therefore, herbaceous species composition of the communal land-use types in our study area differed significantly from the untransformed protected 


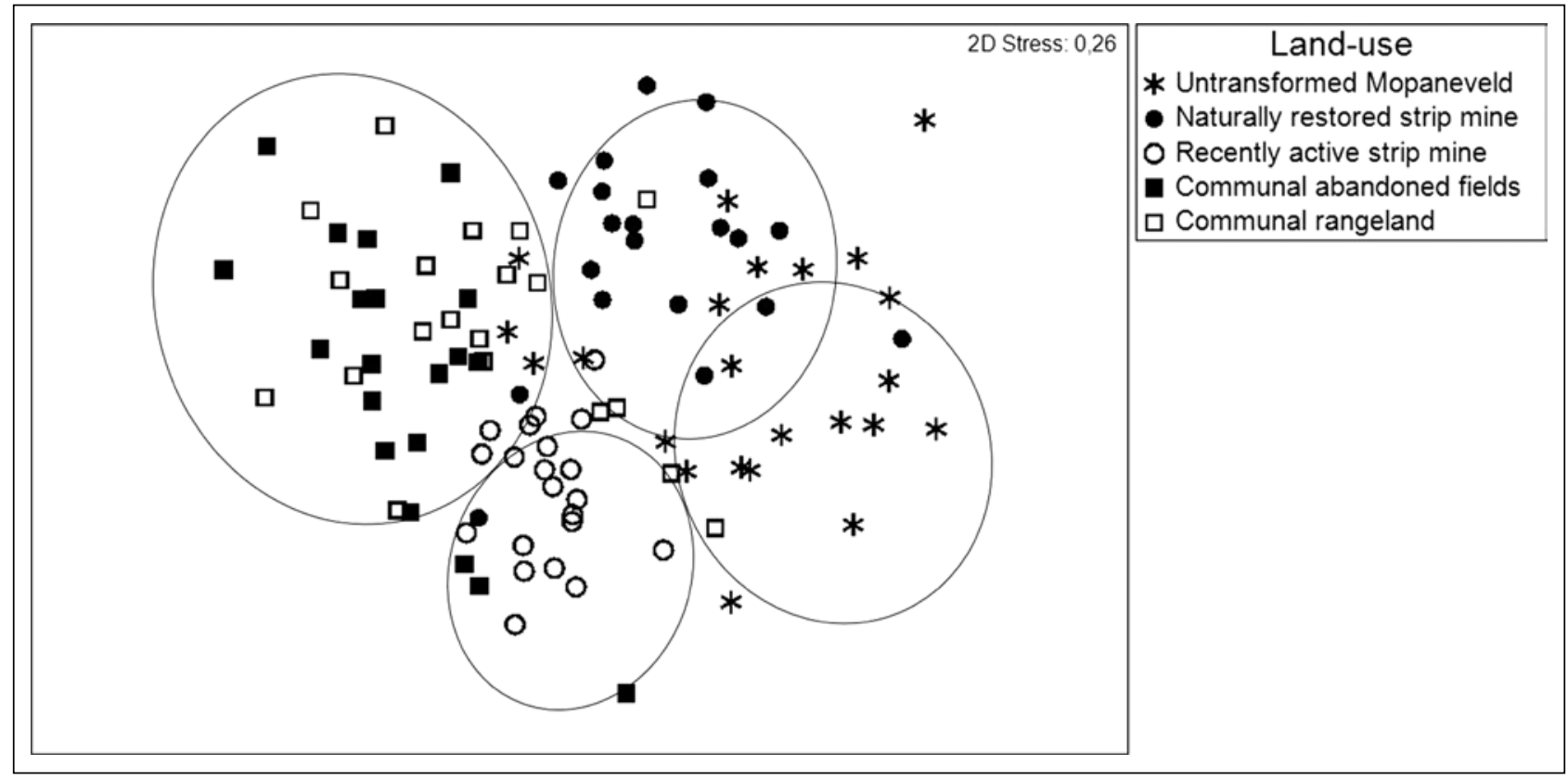

Figure 2. Multidimensional Scaling (NMDS) ordination of sampling plots representing herbaceous species assemblages across land-use types. Broad groupings are encircled.

area $(p<0.001 ; t>2)$. Species composition of the two communal land-use types (i.e. communal rangeland and communal abandoned fields) was not significantly distinct $(p=0.099 ; t<2)$.

Multivariate data dispersion of the strip mining and protected area land-use types was, however significant ( $F$ $=18.86 ; p<0.001)$. Significant differences in species composition among the two strip mining types $(p<$ $0.001 ; t=4.23)$ and the untransformed protected area site $(p<0.001 ; t<2)$, should therefore be interpreted with caution. However, since the recently active strip mining site was exposed to the most recent soil disturbance, it can be expected that species composition in this site may be dominated by a suite of species and traits that are quite distinct from more heterogeneous sites, such as the untransformed protected area site and the naturally restored strip mining site.

\section{Woody density}

The mean woody density, dominated by C. mopane, was highest in the untransformed site $\left(22378 \mathrm{~m}^{2} \mathrm{ha}^{-1}\right.$ \pm 14 595), and higher than the recently active strip mine area (2 $726 \mathrm{~m}^{2} \mathrm{ha}^{-1} \pm 3$ 590) and communal rangeland (4 $572 \mathrm{~m}^{2} \mathrm{ha}^{-1} \pm 9$ 893). Dichrostachys cinerea (L.) Wight \& Arn., and not C. mopane, dominated the woody layer in the transformed land-use types. Since woody density did not correlate with increases or decreases in herbaceous species diversity or biomass (Pearson's correlation coefficient $(-0.5<r<0.5)$ for both variables), herbaceous vegetation changes are assumed to more strongly reflect effects of land-use changes than of local-scale woody density.

\section{Indicator species}

The protected area and the communal abandoned fields hosted the highest richness in indicator species (16 and 18 species respectively). Communal rangelands and recently active strip mines hosted only six indicator species (IndVal $>0.12 ; p<0.05$ ) of which the majority were annual forbs (rangelands) or annual grasses (strip mine) (Table 2). Forbs represented $50 \%$ of all indicator species in the protected area and increased to over $80 \%$ in the naturally restored strip mine, communal rangelands and abandoned fields (Table 2). The abandoned fields in the communal area hosted the most alien indicator species, which included Acanthospermum hispidum DC., Boerhavia cordobensis Kuntze, Gomphrena celosioides Mart. and Schkuhria pinnata (Lam.) Cabrera., although none of these are considered to be alien invasive species. The only two indicator grass species on the abandoned fields were the palatable Sporobolus ioclados (Trin.) Nees and Urochloa panicoides P.Beauv., whereas the communal rangeland indicator grass, Tragus berteronianus Schult. (Table 2), is an annual, disturbance-tolerant species. The recently active strip mine was dominated by the perennial grass Urochloa mosambicensis (Hack.) Dandy. This indicator germinates rapidly from seed in areas prone to soils disturbance. Considering life history, perennial indicator species were favoured by protected and naturally restored land-use types, which also hosted the highest richness in plant families among indicator species (Table 2).

\section{Species and trait diversity}

Land-use type had a significant effect on all measures of herbaceous species richness and diversity (Table 3). 
Table 2. Results of indicator species analysis based on mean herbaceous species counts at the four land-use types in a semi-arid Mopaneveld savanna. Indicator values (IndVal) are accompanied by a p-value based on permutation tests. Only species with a significant indicator value $(\mathrm{p}<0.05)$ are presented

\begin{tabular}{|c|c|c|c|c|c|}
\hline Family & Species & Grass/forb & Life history & IndVal & p-value \\
\hline \multicolumn{6}{|c|}{ Protected Mopaneveld } \\
\hline Malvaceae & Hibiscus micranthus L.f. & Forb & Perennial & 0.46 & 0.001 \\
\hline Fabaceae & Rhynchosia minima (L.) DC. & Forb & Perennial & 0.35 & 0.001 \\
\hline Poaceae & Panicum maximum Jacq. & Grass & Perennial & 0.31 & 0.002 \\
\hline Acanthaceae & Ruellia cordata Thunb. & Forb & Perennial & 0.3 & 0.002 \\
\hline Poaceae & Chloris roxburghiana Schult. & Grass & Perennial & 0.25 & 0.002 \\
\hline Poaceae & Bothriochloa radicans (Lehm.) A.Camus & Grass & Perennial & 0.23 & 0.002 \\
\hline Fabaceae & Indigofera nebrowniana J.B.Gillett & Forb & Perennial & 0.22 & 0.003 \\
\hline Fabaceae & Chamaecrista absus (L.) Irwin \& Barneby & Forb & Annual & 0.2 & 0.012 \\
\hline Poaceae & Aristida scabrivalvis Hack. & Grass & Annual & 0.19 & 0.017 \\
\hline Euphorbiaceae & Tragia rupestris Sond. & Forb & Perennial & 0.17 & 0.014 \\
\hline Sterculiaceae & Melhania acuminata Mast. & Forb & Perennial & 0.17 & 0.006 \\
\hline Euphorbiaceae & Acalypha indica L. & Forb & Annual & 0.16 & 0.04 \\
\hline Verbenaceae & Lantana rugosa Thunb. & Forb & Perennial & 0.16 & 0.013 \\
\hline Boraginaceae & Heliotropium ciliatum Kaplan & Forb & Perennial & 0.13 & 0.028 \\
\hline Convolvulaceae & Ipomoea sinensis (Desr.) Choisy & Forb & Annual & 0.13 & 0.05 \\
\hline Poaceae & Themeda triandra Forssk. & Grass & Perennial & 0.13 & 0.035 \\
\hline \multicolumn{6}{|c|}{ Naturally restored strip mines ( $>30$ years) } \\
\hline Amaranthaceae & Kyphocarpa angustifolia (Moq.) Lopr. & Forb & Annual & 0.45 & 0.001 \\
\hline Fabaceae & Indigofera vicioides Jaub. \& Spach & Forb & Perennial & 0.38 & 0.001 \\
\hline Euphorbiaceae & Phyllanthus parvulus Sond. & Forb & Perennial & 0.28 & 0.006 \\
\hline Poaceae & Melinis repens (Willd.) Zizka & Grass & Annual & 0.24 & 0.002 \\
\hline Malvaceae & Hibiscus sidiformis Baill. & Forb & Annual & 0.24 & 0.007 \\
\hline Poaceae & Heteropogon contortus (L.) Roem. \& Schult. & Grass & Perennial & 0.22 & 0.007 \\
\hline Violaceae & ${ }^{+}$Hybanthus enneaspermus (L.) F.Muell. & Forb & Perennial & 0.2 & 0.002 \\
\hline Amaranthaceae & ${ }^{\dagger}$ Achyranthes aspera L. & Forb & Perennial & 0.2 & 0.009 \\
\hline Convolvulaceae & Seddera suffruticosa (Schinz) Hallier f. & Forb & Perennial & 0.16 & 0.045 \\
\hline Euphorbiaceae & Euphorbia neopolycnemoides Pax \& K.Hoffm. & Forb & Annual & 0.12 & 0.047 \\
\hline
\end{tabular}

\section{Recently active strip mines ( $<15$ years)}

\begin{tabular}{|c|c|c|c|c|c|}
\hline Poaceae & Urochloa mosambicensis (Hack.) Dandy & Grass & Perennial & 0.59 & 0.001 \\
\hline Euphorbiaceae & Phyllanthus incurvus Thunb. & Forb & Perennial & 0.47 & 0.001 \\
\hline Poaceae & Aristida adscensionis L. & Grass & Annual & 0.32 & 0.026 \\
\hline Poaceae & Chloris virgata Sw. & Grass & Annual & 0.28 & 0.007 \\
\hline Poaceae & Aristida bipartita (Nees) Trin. \& Rupr. & Grass & Annual & 0.25 & 0.014 \\
\hline Asteraceae & Dicoma tomentosa Cass. & Forb & Annual & 0.19 & 0.031 \\
\hline \multicolumn{6}{|c|}{ Communal abandoned fields } \\
\hline Portulacaceae & Portulaca hereroensis Schinz & Forb & Annual & 0.46 & 0.001 \\
\hline Amaranthaceae & ${ }^{\dagger}$ Gomphrena celosioides Mart. & Forb & Perennial & 0.39 & 0.001 \\
\hline Acanthaceae & Blepharis integrifolia (L.f.) E.Mey. ex Schinz & Forb & Perennial & 0.39 & 0.001 \\
\hline
\end{tabular}


Table 2. Results of indicator species analysis based on mean herbaceous species counts at the four land-use types in a semi-arid Mopaneveld savanna. Indicator values (IndVal) are accompanied by a p-value based on permutation tests. Only species with a significant indicator value $(p<0.05)$ are presented (continued)

\begin{tabular}{|c|c|c|c|c|c|}
\hline Family & Species & Grass/forb & Life history & IndVal & p-value \\
\hline \multicolumn{6}{|c|}{ Communal abandoned fields (continued) } \\
\hline Tiliaceae & Corchorus confusus Wild & Forb & Perennial & 0.34 & 0.036 \\
\hline Molluginaceae & Hypertelis bowkeriana Sond. & Forb & Perennial & 0.26 & 0.002 \\
\hline Portulacaceae & Portulaca trianthemoides Bremek. & Forb & Annual & 0.26 & 0.005 \\
\hline Polygonaceae & $\begin{array}{l}\text { Oxygonum sinuatum (Hochst. \& Steud. ex } \\
\text { Meisn.) Dammer }\end{array}$ & Forb & Annual & 0.23 & 0.014 \\
\hline Nyctaginaceae & ${ }^{\dagger}$ Boerhavia cordobensis Kuntze. & Forb & Annual & 0.21 & 0.005 \\
\hline Poaceae & Sporobolus ioclados (Trin.) Nees & Grass & Perennial & 0.2 & 0.005 \\
\hline Gisekiaceae & Gisekia africana (Lour.) Kuntze & Forb & Annual & 0.17 & 0.013 \\
\hline Molluginaceae & Limeum dinteri G.Schellenb. & Forb & Perennial & 0.16 & 0.021 \\
\hline Pedaliaceae & Ceratotheca triloba (Bernh.) Hook.f. & Forb & Annual & 0.16 & 0.015 \\
\hline Poaceae & Urochloa panicoides P.Beauv. & Grass & Annual & 0.15 & 0.042 \\
\hline Asteraceae & ${ }^{\dagger}$ Acanthospermum hispidum DC. & Forb & Annual & 0.15 & 0.016 \\
\hline Asteraceae & ${ }^{+}$Schkuhria pinnata (Lam.) Cabrera & Forb & Annual & 0.15 & 0.025 \\
\hline Sterculiaceae & Hermannia boraginiflora Hook. & Forb & Perennial & 0.15 & 0.028 \\
\hline Fabaceae & Crotalaria distans Benth. & Forb & Annual & 0.13 & 0.023 \\
\hline Fabaceae & Crotalaria steudneri Schweinf. & Forb & Annual & 0.13 & 0.023 \\
\hline \multicolumn{6}{|c|}{ Communal rangeland } \\
\hline Fabaceae & Zornia glochidiata DC. & Forb & Annual & 0.3 & 0.009 \\
\hline Poaceae & Tragus berteronianus Schult. & Grass & Annual & 0.24 & 0.028 \\
\hline Molluginaceae & ${ }^{\dagger}$ Mollugo nudicaulis Lam. & Forb & Annual & 0.22 & 0.009 \\
\hline Molluginaceae & Limeum viscosum (J.Gay) Fenzl & Forb & Annual & 0.19 & 0.002 \\
\hline Portulacaceae & Portulaca quadrifida L. & Forb & Annual & 0.19 & 0.02 \\
\hline Acanthaceae & Barleria senensis Klotzsch & Forb & Perennial & 0.15 & 0.024 \\
\hline
\end{tabular}

${ }^{+}$Alien plant species

The land-use type with recent ( $<15$ years) strip mining activities was the only to reveal significant deviations from the benchmark (i.e. untransformed protected area) mean values for all diversity measures (Figure $3 ; p$ $<0.05)$. Species evenness was also significantly lower in the abandoned fields $(p=0.018)$ compared to the protected area (Figure 3).

Significant land-use type effects on trait diversity measures were revealed for total trait richness, Margalef trait richness and Simpson trait diversity (Table 3). Functional trait measures of diversity across transformed land-use types revealed weak deviations from the benchmark means (i.e. untransformed/protected area), with the exception of significantly lower Simpson trait diversity recorded for the recently active strip mining area (Figure $3 ; p<0.05)$. Margalef trait richness deviated significantly from the benchmark means for the abandoned fields $(p<0.001)$ and both the recently active $(p<$
$0.001)$ and naturally restored $(p=0.037)$ strip mining sites (Figure 3). Functional trait evenness index values were almost equal to the benchmark means across all land-use types (Figure 3).

\section{Plant functional types}

Cluster analyses assisted in the identification of 21 plant functional types (PFT's). Shade tolerance initiated the highest hierarchical separation in annual grasses (PFT 1-3; Figure S2), followed by growth form, although perennial grasses (PFT 7-10; Figure S3) were strongly separated according to their ability to resprout at, or below the soil surface. Lower hierarchical clustering of perennial grasses was initiated by shade tolerance. In annual forbs (PFT 4-6; Figure S4), the first level clustering was initiated by their ability to fix nitrogen, followed by seed dispersal mode. Perennial forbs were rich in PFT's 
Table 3. Linear mixed model fixed effects of land-use type on measures of diversity. Significance $(p<0.05)$ are indicated with an asterisk $\left.{ }^{*}\right)$. $d f$, degrees of freedom; Num., numerator; Den., denominator; SE, standard error

\begin{tabular}{|c|c|c|c|c|c|c|c|c|c|c|}
\hline & \multicolumn{2}{|c|}{$d f$} & \multicolumn{4}{|c|}{ Residual } & \multicolumn{2}{|c|}{$\mathbf{F}$} & \multicolumn{2}{|c|}{ Sig } \\
\hline & Num. & Den. & Estir & nates & & E & & & & \\
\hline & & & Species & Traits & Species & Traits & Species & Traits & Species & Traits \\
\hline Total richness & 4 & 46 & 22.41 & 1.480 & 4.44 & 0.293 & 5.523 & 3.561 & $0.001^{*}$ & $0.013^{*}$ \\
\hline Margalef richness & 4 & 46 & 0.966 & 0.062 & 0.191 & 0.012 & 7.561 & 13.119 & $<0.001^{*}$ & $<0.001^{*}$ \\
\hline Simpson diversity & 4 & 46 & 0.030 & $<0.001$ & 0.006 & $<0.001$ & 4.366 & 4.879 & $0.004^{*}$ & $0.002^{*}$ \\
\hline Pielou evenness & 4 & 46 & 0.025 & 0.002 & 0.005 & $<0.001$ & 4.759 & 1.908 & $0.003 *$ & 0.125 \\
\hline
\end{tabular}

(PFT 11-21; Figure S5) that were clustered according to their ability to resprout at or below the soil surface, ability to fix nitrogen, growth form and shade tolerance (in descending order of hierarchical levels) (Figure S4). Plant trait descriptions are presented in Table 4.

The first two axes (Principal Components) of the PCA explained $36.96 \%$ of variance observed in PFT data (Axis $1=21.65 \%$; Axis $2=15.32 \%$; Figure 4). The largest contribution of the variance within PFTs (21.65\%) was explained by the first principal component (Axis 1;
Figure 4), which was mainly correlated with soil disturbance, including ploughing (i.e. abandoned crop fields) and ripping (recently active strip mining area). Nitrogen-fixing annual forbs (PFT 4) and perennial forbs, with a prostrate growth form and the ability to resprout at or near the soil surface (PFT 18), were strongly correlated with abandoned crop fields of communal areas, whereas annual forbs without nitrogen-fixing abilities (PFT's 5 and 6) were associated with both types of communal land-uses (abandoned fields and rangelands). Perennial grasses growing in full sun, with a prostrate,

Table 4. Descriptive summary of plant functional groups and their respective plant functional types (PFT's)

\begin{tabular}{|c|c|c|}
\hline Plant functional group & Plant functional type & Description of PFT \\
\hline \multirow[t]{3}{*}{ Annual grasses } & PFT1 & Annual, shade-tolerant tussock grasses \\
\hline & PFT2 & Annual prostrate grasses \\
\hline & PFT3 & Annual tussock grasses \\
\hline \multirow[t]{3}{*}{ Annual forbs } & PFT4 & Annual, nitrogen-fixing forbs \\
\hline & PFT5 & Annual, auto- or anemochorous forbs \\
\hline & PFT6 & Annual zoochorous forbs \\
\hline \multirow[t]{4}{*}{ Perennial grasses } & PFT7 & Perennial, shade-tolerant, non-resprouting grasses \\
\hline & PFT8 & Perennial non-resprouting grasses \\
\hline & PFT9 & Perennial resprouting grasses \\
\hline & PFT10 & Perennial, shade-tolerant, resprouting grasses \\
\hline \multirow[t]{11}{*}{ Perennial forbs } & PFT11 & Perennial, shade-tolerant climbers \\
\hline & PFT12 & Perennial, erect, shade-tolerant forbs \\
\hline & PFT13 & Perennial, erect forbs \\
\hline & PFT14 & Perennial, resprouting climbers \\
\hline & PFT15 & Perennial, Nitrogen-fixing, resprouting climbers \\
\hline & PFT16 & Perennial, Nitrogen-fixing, erect, resprouting forbs \\
\hline & PFT17 & Perennial, resprouting creeping forbs \\
\hline & PFT18 & Perennial, prostrate resprouting forbs \\
\hline & PFT19 & Perennial, erect, shade-tolerant, resprouting forbs \\
\hline & PFT20 & Perennial, erect, resprouting forbs \\
\hline & PFT21 & Perennial goephytes and sedges \\
\hline
\end{tabular}




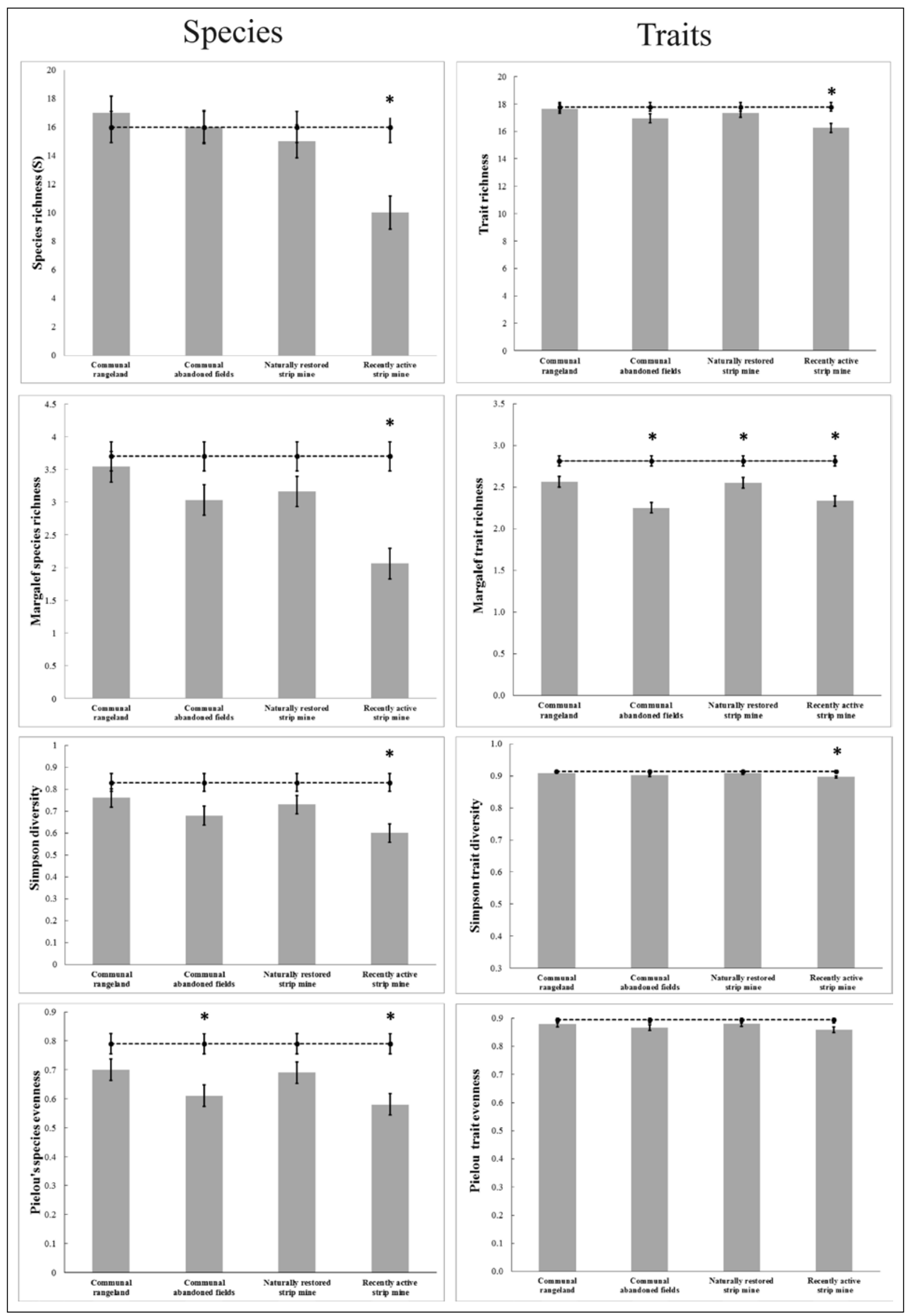

Figure 3. Herbaceous species (left) and trait (right) diversity measures benchmarked against the mean value calculated for the untransformed (protected) area (----) across transformed land-use types. Vertical bars denote 0.95 confidence intervals. Significant deviations from the protected area (Sidak posthoc pairwise comparison; $p<0.05$ ) are denoted by $(*)$. 


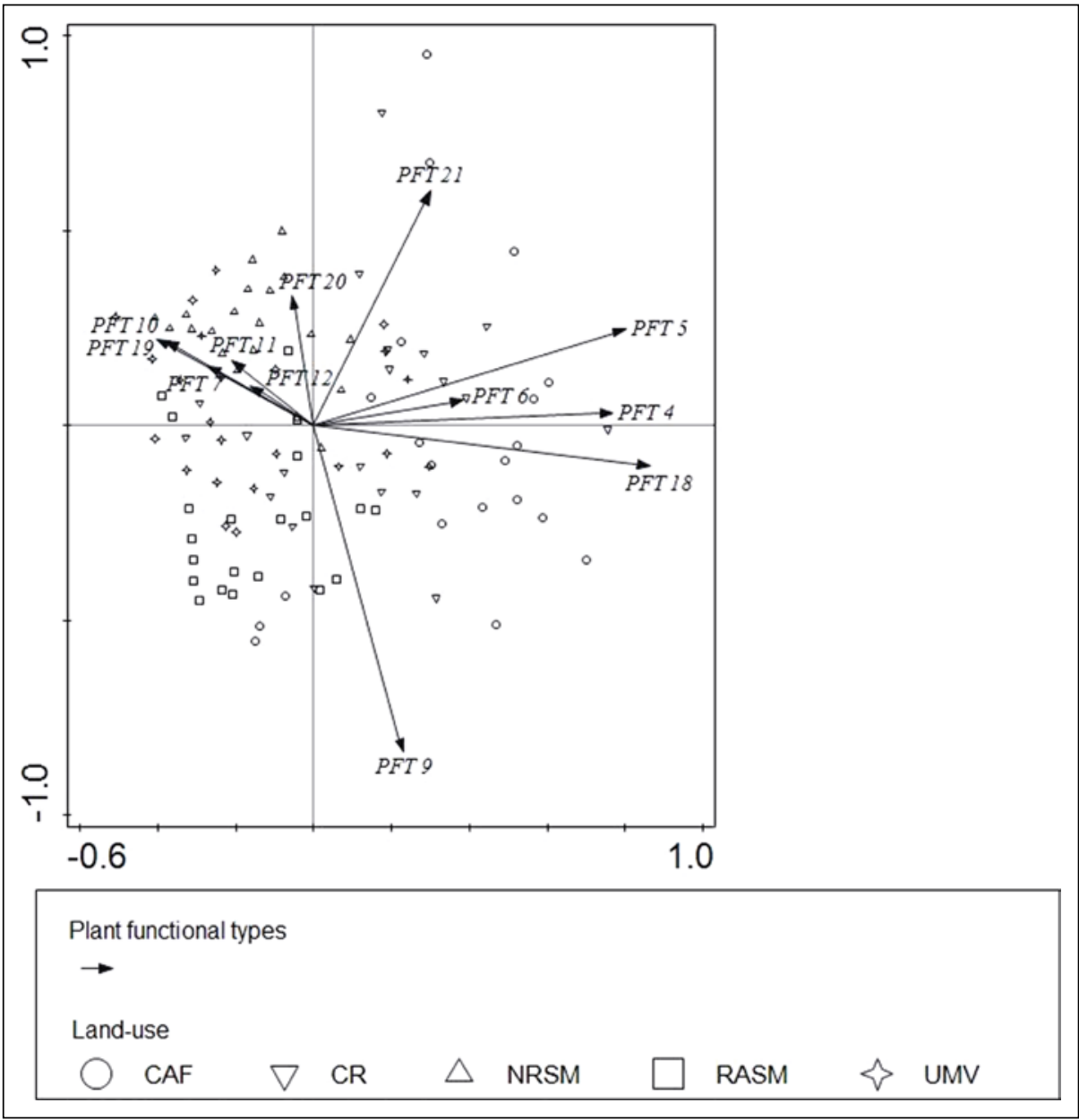

Figure 4. Principal Component Analysis (PCA) ordination of land-use type sampling plots correlated with plant functional types (PFT's). CAF (Communal abandoned fields); CR (Communal rangelands); NRSM (Naturally restored strip mine); RASM (Recently active strip mine); UMV (Untransformed Mopaneveld).

stoloniferous growth form (PFT 9) were favoured by all land-use types, except for the naturally restored strip mine, with which shade-tolerant grass and forb PFT's were correlated (PFT's 7, 10,11,12-19). Perennial forbs with an erect growth form and the ability to resprout below or near the soil surface (i.e. forbs of which the stems may become lignified, but of which the woody stems are consumed by fire and/or herbivory) (PFT 20) were associated with naturally restored strip mined areas (Figure 4). There is no clear relationship between any PFT's and untransformed Mopaneveld, indicating that no PFT defines this land-use.

\section{Discussion}

\section{Degraded land-use effects}

Land-use contrasts are commonly used to analyse corresponding effects on spatiotemporal vegetation and biodiversity patterns in African savanna ecosystems. The majority of such studies have focused on the contrast between high intensity grazing in communal rangelands (perceived as degraded landscapes) opposed to protected areas (e.g. Shackleton 2000; Rutherford, Powrie \& Thompson 2012; Hanke et al. 2014;
Zerbo et al. 2016). Communal land-use practices with dissimilar soil disturbance histories (e.g. rangelands versus abandoned, bush-cleared croplands) were expected to display disparate herbaceous species assemblages (Hiernaux et al. 2009; Kellner et al. 2021), but this was not supported by our results. Weak negative effects of different communal land-use practices on species composition in this study suggest that long-term exposure to regular disturbances may induce tolerance to such events (Rutherford, Powrie \& Thompson 2012).

The maintenance of species richness, diversity and evenness in the communal rangeland supported previous findings of Rutherford, Powrie and Thompson (2012) and Shackleton (2000). Large herbivores are known to maintain species richness and diversity through their suppressive effects on standing herbaceous biomass, albeit through grazing and browsing by wild game in protected areas (Van Coller \& Siebert 2015), or by livestock in communal rangelands (Zerbo et al. 2016).

Conservation management is generally directed towards protecting species numbers as diversity may enhance temporal stability, a mechanism referred to as the insurance hypothesis (Yachi \& Loreau 1999). In contrast, the effects of disrupted evenness on ecosystem stability 
are less explored (Crowder et al. 2010; Mori, Farukawa \& Sasaki 2013). Low species evenness displayed by the abandoned fields implies dominance of a few disturbance-tolerant species, a common result of human-induced environmental degradation (Hillebrand, Bennet \& Cadotte 2008; Wittebolle et al. 2009). Such communities are often more susceptible to invasion (Mason et al. 2005; Crowder et al. 2010) and are expected to be less resilient to disturbances. Indicator species analyses partially supported this hypothesis, as over $50 \%$ of the indicator species on the abandoned fields were annuals, of which the majority were alien species. Linking PFT's with land-uses supported these results as the PFT's that correlated strongly with the abandoned fields were ruderal, disturbance-adapted species, which included annual forbs, some with the ability to fix nitrogen, and perennial, prostrate forbs with the ability to resprout after disturbances such as fire, herbivory or drought stress. These results can be interpreted as yet another example of a typical trait syndrome of herbaceous plants subjected to defoliation, such as grazing (Moreno Garcia et al. 2014), although our results highlight the significance of forbs as useful indicators of potential regime shifts (Siebert \& Dreber 2019).

Evidence of negative effects of communal land-use types on ecosystem stability could not be provided. Although both communal land-use types hosted a lower trait richness than the protected area, trait evenness and diversity were maintained at both sites, suggesting trait-based redundancy. Trait-based redundancy is provided through dominant stress-tolerant species with similar trait sets that contribute to functional compensation for the species that were lost from the community (Lavorel et al. 2011), a mechanism that provides ecosystem stability (Mori, Farukawa \& Sasaki 2013). These findings support previous findings that functional trait diversity patterns, including evenness, better explain disturbance effects than biodiversity loss only (Vandewalle et al. 2010; Hanke et al. 2014).

\section{Urban land-use effects}

Mining activities are known to have direct and indirect effects on biodiversity through habitat destruction and soil disturbances (Yan, Zhao \& Sun 2013), which may ultimately lead to diversity loss and homogenisation of plant communities if alien species colonise this land-use type (Dassonville et al. 2008). Strip mining practices did not lead to homogenisation of herbaceous plant communities since species composition among the two strip mining land-use types was quite distinct. Species composition in the recently active strip mining site differed from both the naturally restored strip mining site and the untransformed protected area. These results support the expected negative effects of topsoil disturbance on plant species composition (Lubke, Avis \& Moll 1996). However, such vegetation states may be temporal, explaining heterogeneity among the strip mining land-use types, which was driven by native annual grasses as the only indicator species for the recently active mining site. Herbaceous communities on the naturally restored sites (i.e. soil disturbance which occurred over 30 years ago) hosted species assemblages comparable to the protected area. This is in accordance with results from coastal dune rehabilitation studies, where sites with a longer history of limited rehabilitation interferences revealed vegetation states comparable to unmined communities (Van Aarde et al. 1996). Moreover, as the strip mine sites were left to rejuvenate without human interference, the presence of biodiversity islands comprising patches of untransformed areas (nearby species pool) could have enhanced the recovery of species assemblages in the naturally restored strip mine site.

Contrary to the weak communal land-use effects on herbaceous community diversity, the significant effects of strip mining practices suggest strong filtering effects imposed by this land-use type. Strip mining practices are associated with topsoil disturbances, which include removal of the seed- and belowground bud banks, soil compaction, decreased soil fertility, exposure to soil erosion and increased soil temperature (Shrestha \& Lal 2011). Few plant species possess all the necessary traits to tolerate such disturbances, which explains the low species and functional richness within these communities. Conservation biology literature often relates such species richness declines with similar losses in ecosystem function (e.g. Cardinale et al. 2006). However, this relationship was only evident for the strip mined areas where both species and trait losses were evident. Plant communities of communal areas were less affected by land-use intensification whereas natural recovery of mining sites was largely context-specific (i.e. disturbance type, duration and the size of the surrounding species pool) (Mayfield et al. 2010). For instance, the older strip mined areas without any re-vegetation practices since the 1980s, were able to retain their function (in terms of PFTs) in this particular ecosystem, despite their exposure to a perceived destructive event. This maintenance of ecosystem function could be explained by the presumed influx of species from the species pool in the surrounding untransformed, protected area. This implies that community processes in transformed Mopaneveld have the ability to tolerate disturbance events without direct human intervention, provided that the affected area is surrounded by natural vegetation seed sources as the soil seed bank is lost during mining.

Mining land-uses had pronounced habitat filtering effects. This was especially evident through the significant loss of functional richness and diversity in the recently active strip mined area, which is in accordance with the land-use intensification hypotheses (e.g. Pakeman 2011). Contrariwise, functional trait evenness was maintained, suggesting the lack of dominance of one or more plant traits over others in these transformed 
landscapes. When resource availability is assumed to be even across niche space, functional evenness reflects the optimal utilisation of resources, which suggest that higher functional evenness will decrease the opportunity for undesirable plant groups, such as invader species to fill the niche space (Mason et al. 2005). High functional evenness in urban land-use types therefore infers the maintenance of ecosystem function despite species richness declines (Mason et al. 2005), although land-use intensification will reduce functional redundancy in the long-term (Lalibarté et al. 2010).

\section{Conclusions}

Herbaceous plant communities in a South African semi-arid Mopaneveld savanna are more stress-tolerant than expected, although some non-invasive alien weeds took over the function of lost species on abandoned fields. Although species and their respective functional traits were indeed affected by land-use types, the severity of the effects varied across disturbance intensity and among response variables. Despite these varying effects on herbaceous species and functional diversity, our results suggest that ecosystem functioning in this semi-arid Mopaneveld could be maintained. Predictions on increasing frequencies and intensities of land-use and climate change may push the functioning of Mopaneveld ecosystems beyond their ecological boundaries. However, our study suggests that the current state of herbaceous communities can be maintained through continued appropriate management of multi-functional landscapes in the Phalaborwa region. These results, however, do not reflect the potential negative effects imposed by large-scale commercial agricultural practices and active mining operations in the area. For subsistence-based land-use transformation, our study supported the value of protected areas surrounding transformed land-use types, as these areas aid with natural rehabilitation of plant communities. Diversity measures that include evenness are important to detect dominance shifts in semi-arid terrestrial savanna ecosystems as it better explains ecosystem resilience than richness and diversity alone. Furthermore, our results confirmed that the assessment of land-use effects on biodiversity at species level only, may be deceptive. Results from this study reflected contrasting effects of land-use change when species-based diversity index values are compared to functional trait-based changes. Complementary biodiversity measures (i.e. species and functional measures) should be included to achieve a comprehensive assessment of land-use effects on biodiversity patterns in semi-arid ecosystems.

\section{Acknowledgements}

We would like to thank Palabora Mining Company for providing access to their land. We acknowledge the fieldwork assistance of Lerato Mabe, Zander Liebenberg and Bianca Greyvenstein. Marié du Toit prepared the map. We thank SANParks for providing accommodation. The financial assistance and logistical support of the South African Environmental Observation Network (SAEON) towards this research is hereby acknowledged. Opinions expressed and conclusions arrived at, are those of the authors and are not necessarily to be attributed to SAEON.

\section{Authors' contributions}

FS and SJS (North-West Unversity) were the project leaders, who took the lead in writing the manuscript. NvS was responsible for data collection, analyses and reporting. DMK (North-West University) assisted with data collection, plant identifications, data management and preliminary analyses. AMS (SAEON) was responsible for the study design, student supervision and logistical support.

\section{Disclaimer}

The views expressed in the submitted article are our own and not an official position of the institution or funder.

\section{Source(s) of support}

South African Environmental Observation Network, National Research Foundation, Unit for Environmental Sciences and Management.

\section{References}

Anderson, M.J., Ellingsen, K.E. \& McArdle, B.H., 2006, 'Multivariate dispersion as a measure of beta diversity', Ecology Letters, 9(6), 683-693, https://doi.org/10.1111/j.14610248.2006.00926.x
Anderson, M.J. \& Walsh, D.C., 2013, 'PERMANOVA, ANOSIM, and the Mantel test in the face of heterogeneous dispersions: What null hypothesis are you testing?', Ecological Monographs, 83(4), 557-574, https://doi.org/10.1890/12-2010.1 
Botha, M., Siebert, S.J., Van den Berg, J., Ellis, S. \& Dreber, N., 2017, 'Plant functional types differ between the grassland and savanna biomes along an agro-ecosystem disturbance gradient in South Africa', South African Journal of Botany, 113, 308-317, https://doi.org/10.1016/j. sajb.2017.09.008

Botta-Dukát, Z., 2005, 'Rao's quadratic entropy as a measure of functional diversity based on multiple traits', Journal of Vegetation Science, 16(5), 533-540, https://doi. org/10.1111/j.1654-1103.2005.tb02393.x

Cardinale, B.J., Srivastava, D.S., Duffy, J.E., Wright, J.P., Downing, A.L., Sankaran, M. \& Jouseau, C., 2006, 'Effects of biodiversity on the functioning of trophic groups and ecosystems', Nature, 443(7114), 989-992, doi: 10.1038/nature05202

Clarke, K.R., Somerfield, P.J. \& Gorley, R.N., 2008, 'Testing of null hypotheses in exploratory community analyses: similarity profiles and biota-environment linkage', Journal of Experimental Marine Biology and Ecology, 366(1):56-69, doi: 10.1016/j.jembe.2008.07.009

Crowder, D.W., Northfield, T.D., Strand, M.R. \& Snyder, W.E., 2010, 'Organic agriculture promotes evenness and natural pest control', Nature, 466(7302), 109-112, DOI: 10.1038/nature09183

Dassonville, N., Vanderhoeven, S., Vanparys, V., Hayez, M., Gruber, W., \& Meerts, P., 2008, 'Impacts of alien invasive plants on soil nutrients are correlated with initial site conditions in NW Europe', Oecologia, 157(1), 131-140, https://doi.org/10.1007/s00442-008-1054-6

Dudley, N., Jonas, H., Nelson, F., Parrish, J., Pyhälä, A., Stolton, S. \& Watson, J., 2018, 'The essential role of other effective area-based conservation measures in achieving big bold conservation targets', Global Ecology and Conservation, 15, e00424, https://doi.org/10.1016/j.gecco.2018.e00424

Dufrêne, M. \& Legendre, P., 1997, 'Species assemblages and indicator species: the need for a flexible asymmetrical approach', Ecological Monographs, 67(3), 345-366, DOI: $10.2307 / 2963459$

Fox, H.V., Bonnet, O., Cromsigt, J.P., Fritz, H. \& Shrader, A.M., 2015, 'Legacy effects of different land-use histories interact with current grazing patterns to determine grazing lawn soil properties', Ecosystems, 18(4), 720-733.

Germishuizen, G., 1997, Wild flowers of northern South Africa. Vlaeberg: Fernwood Press.

Germishuizen, G. \& Meyer, N.L., 2003, Plants of southern Africa: An annotated checklist, Strelitzia 14. Pretoria: National Botanical Institute.

Gray, C.L., Hill, S., Newbold, T., Hudson, L.N., Börger, L., Contu, S., Hoskins, A.J., Ferrier, S., Purvis, A. \& Scharlemann, J.G.W., 2016, 'Local biodiversity is higher inside than outside terrestrial protected areas worldwide', Nature Communications, 7,12306, DOI: 10.1038/ncomms12306

Hanke, W., Böhner, J., Dreber, N., Jürgens, N., Schmiedel, U., Wesuls, D. \& Dengler, J., 2014, 'The impact of livestock grazing on plant diversity: an analysis across dryland ecosystems and scales in southern Africa', Ecological Applications, 24(5), 1188-1203, DOI: 10.1890/13-0377.1

Herrero-Jáuregui, C. \& Oesterheld, M., 2018, 'Effects of grazing intensity on plant richness and diversity: A meta-analysis', Oikos, 127(6), 757-766, https://doi.org/10.1111/oik.04893

Hiernaux, P., Ayantunde, A., Kalilou, A., Mougin, E., Gérard, B., Baup, F., Grippa, M. \& Djaby, B., 2009, 'Trends in productivity of crops, fallow and rangelands in Southwest Niger: Impact of land use, management and variable rainfall', Journal of Hydrology, 375(1-2), 65-77, https://doi. org/10.1016/j.jhydrol.2009.01.032

Hillebrand, H., Bennett, D.M. \& Cadotte, M.W., 2008, 'Consequences of dominance: a review of evenness effects on local and regional ecosystem processes', Ecology, 89(6), 1510-1520, https://doi.org/10.1890/07-1053.1

Hill, D., 2005, Handbook of biodiversity methods: Survey, evaluation and monitoring, Cambridge: Cambridge University Press.

Hustrulid, W.A., 2013, Strip mining. Encyclopedia Britannica, Available at: http://global.britannica.com/EBchecked/topic/569236/strip-mining (Accessed: 8 May 2014).

IBM Corp., 2016, IBM SPSS Statistics for Windows, Version 24.0, Armonk: IBM Corp.

JSTOR, 2015, Global Plants, Available at: https://plants.jstor. org (Accessed: 1 June 2015).

Kellner, K., Mangani, R., Sebitloane, T., Chirima, J., Meyer, N., Coetzee, H., Malan, P. \& Koch, J., 2021, 'Restoration after bush control in selected rangeland areas of the semi-arid savanna in South Africa', Bothalia, 51(1): 93-105 (hardcopy); 1-13 (online) [this issue].

Laliberte, E., Wells, J.A., DeClerck, F., Metcalfe, D.J., Catterall, C.P., Queiroz, C., Aubin, I., Bonser, S.P., Ding, Y., Fraterrigo, J.M., McNamara, S., Morgan, J.W., Sánches M, D., Vesk, P.A. \& Mayfield, M.M., 2010, 'Land-use intensification reduces functional redundancy and response diversity in plant communities', Ecology Letters, 13(1), 76-86.

Lavorel, S., Mclntyre, S., Landsberg, J. \& Forbes, T.D.A., 1997, 'Plant functional classifications: from general groups to specific groups based on response to disturbance', Trends in Ecology \& Evolution, 12(12), 474-478, https:// doi.org/10.1016/S0169-5347(97)01219-6

Lavorel, S., De Bello, F., Grigulis, K., Lepš, J., Garnier, E., Castro, H., Dolezal, J., Godolets, C., Quétier, F. \& Thébault, A., 2011, 'Response of herbaceous vegetation functional diversity to land use change across five sites in Europe and Israel', Israel Journal of Ecology \& Evolution, 57(1-2), 53-72, https://doi.org/10.1560/IJEE.57.1-2.53

Lepš, J. \& Šmilauer, P., 2003, Multivariate analysis of ecological data using CANOCO. Cambridge: Cambridge University Press.

Linstädter, A., Schellberg, J., Brüser, K., García, C.A.M., Oomen, R.J., du Preez, C.C., Ruppert, J.C. \& Ewert, F., 2014, 'Are there consistent grazing indicators in drylands? Testing plant functional types of various complexity in South Africa's grassland and savanna biomes', PLoS One, 9(8), e104672, https://doi.org/10.1371/journal.pone.0104672

Lubke, R., Avis, A. \& Moll, J., 1996, 'Post-mining rehabilitation of coastal sand dunes in Zululand South Africa', Landscape and Urban Planning, 34(3-4), 335-345.

Mason, N.W.H., Mouillot, D., Lee, W.G. \& Wilson, J.B., 2005, 'Functional richness, functional evenness and functional divergence: The primary components of functional diversity', Oikos, 111(1), 112-118, DOI: 10.1111/j.00301299.2005.13886.x

Mayfield, M.M., Bonser, S.P., Morgan, J.W., Aubin, I., McNamara, S. \& Vesk, P.A., 2010, 'What does species richness tell us about functional trait diversity? Predictions and evidence for responses of species and functional trait diversity to land-use change', Global Ecology and Biogeography, 19(4), 423-431, https://doi.org/10.1111/j.1466-8238.2010.00532.x 
Moreno García, C.A., Schellberg, J., Ewert, F., Brüser, K., Canales-Prati, P., Linstädter, A., Oomen, R.J., Ruppert, J.C. \& Perelman, S.B., 2014, 'Response of communityaggregated plant functional traits along grazing gradients: insights from African semi-arid grasslands', Applied Vegetation Science, 17(3), 470-481, https://doi.org/10.1111/avsc.12092

Mori, A.S., Furukawa, T. \& Sasaki, T., 2013, 'Response diversity determines the resilience of ecosystems to environmental change', Biological Reviews 88(2), 349-364, https://doi. org/10.1111/brv.12004

Mucina, L. \& Rutherford, M.C., 2006, The vegetation of South Africa, Lesotho and Swaziland, Strelitzia 19. Pretoria: South African National Biodiversity Institute.

Newbold, T., Hudson, L.N., Hill, S.L., Contu, S., Lysenko, I., Senior, R.A., Börger, L., Bennett, D.J., Choimes, A. \& Collen, B., 2015, 'Global effects of land use on local terrestrial biodiversity', Nature, 520(7545), 45-50, doi: 10.1038/ nature 14324

Osborne, C.P., Charles-Dominique, T., Stevens, N., Bond, W.J., Midgley, G. \& Lehmann, C.E., 2018, 'Human impacts in African savannas are mediated by plant functional traits', New Phytologist, 220(1), 10-24 https://doi. org/10.1111/nph.15236

Pakeman, R.J., 2011, 'Functional diversity indices reveal the impacts of land use intensification on plant community assembly', Journal of Ecology, 99(5), 1143-1151, https://doi. org/10.1111/j.1365-2745.2011.01853.x

Peco, B., Carmona, C.P., De Pablos, I. \& Azcárate, F.M., 2012, 'Effects of grazing abandonment on functional and taxonomic diversity of Mediterranean grasslands', Agriculture, Ecosystems and Environment, 152, 27-32, DOI: 10.1016/j.agee.2012.02.009

Pérez-Harguindeguy, N., Díaz, S., Garnier, E., Lavorel, S., Poorter, H., Jaureguiberry, P., Bret-Harte, M.S., Cornwell, W.K., Craine, J.M., Gurvich, D.E., Urcelay, C., Veneklaas, E.J., Reich, P.B., Poorter, L., Wright, I.J., Ray, P., Enrico, L., Pausas, J.G., De Vos, A.C., Buchmann, N., Funes, G., Quétier, F., Hodgson, J.G., Thompson, K., Morgan, H.D., Ter Steege, H., Van der Heijden, M.G.A., Sack, L., Blonder, B., Poschlod, P., Vaieretti, M.V., Conti, G., Staver, A.C., Aquino, S. \& Cornelissen, J.H.C., 2013, 'New handbook for standardised measurement of plant functional traits worldwide', Australian Journal of Botany, 61(3), 167-234, doi: 10.1071/BT12225

Primer 6, 2012, Primer 6 version 1.1.15, Plymouth: PRIMER-E Ltd.

Roberts, D.W., 2019, Package 'labdsv', Available at: https:// cran.r-project.org/web/packages/labdsv/labdsv.pdf (Accessed: 28 September 2019).

RStudio Team, 2015, 'RStudio Integrated Development for R', Boston: RStudio.

Rutherford, M.C., Powrie, L.W. \& Thompson, D.I., 2012, 'Impacts of high utilisation pressure on biodiversity components in Colophospermum mopane savanna', African Journal of Range \& Forage Science, 29(1), 1-11, DOI: 10.2989/10220119.2012.687039

Scholes, R.J. \& Biggs, R., 2005, 'A biodiversity intactness index', Nature, 434(7029), 45-49, doi: 10.1038/nature03289

Shackleton, C.M., 2000, 'Comparison of plant diversity in protected and communal lands in the Bushbuckridge lowveld savanna, South Africa', Biological Conservation, 94(3), 273-285.
Shrestha, R.K. \& Lal, R., 2011, 'Changes in physical and chemical properties of soil after surface mining and reclamation', Geoderma, 161(3), 168-176, DOI: 10.1016/j. geoderma.2010.12.015

Siebert, F., Eckhardt, H.C. \& Siebert, S.J., 2010, 'The vegetation and floristics of the Letaba exclosures, Kruger National Park, South Africa', Koedoe, 52(1), 1-12, DOI: 10.4102/ koedoe.v52i1.777

Siebert, F. \& Dreber, N., 2019, 'Forb ecology research in dry savannas: knowledge, gaps and future perspectives', Ecology and Evolution, 9(13), 7875-7891, https://doi. org/10.1002/ece3.5307

Siebert, F., Klem, J. \& Van Coller, H., 2020, 'Forb community responses to an extensive drought in two contrasting landuse types of a semi-arid Lowveld savanna', African Journal of Range and Forage Science, 37(1), 53-64, https://doi.org $/ 10.2989 / 10220119.2020 .1726464$

Šmilauer, P. \& Lepš, J., 2014, Multivariate Analysis of Ecological Data using CANOCO 5, 2nd edition. Cambridge: Cambridge University Press.

Van Aarde, R.J., Ferreira, S.M., Kritzinger, J.J., Van Dyk, P.J., Vogt, M. \& Wassenaar, T.D., 1996, 'An evaluation of habitat rehabilitation on coastal dune forests in northern KwaZulu-Natal, South Africa', Restoration Ecology, 4(4), 334-345.

Van Coller, H. \& Siebert, F., 2015, 'Herbaceous biomassspecies diversity relationships in nutrient hotspots of a semi-arid African riparian ecosystem', African Journal of Range \& Forage Science, 32(3), 213-223, https://doi.org/ $10.2989 / 10220119.2014 .951394$

Van Coller, H., Siebert, F., Scogings, P.F. \& Ellis, S., 2018, 'Herbaceous responses to herbivory, fire and rainfall variability differ between grasses and forbs', South African Journal of Botany, 119, 94-103, DOI: 10.1016/j.sajb.2018.08.024

Van Oudtshoorn, F., 2009, Guide to grasses of Southern Africa. Pretoria: Briza.

Vandewalle, M., De Bello, F., Berg, M.P., Bolger, T., Doledec, S., Dubs, F., Feld, C.K., Harrington, R., Harrison, P.A. \& Lavorel, S., 2010, 'Functional traits as indicators of biodiversity response to land use changes across ecosystems and organisms', Biodiversity and Conservation 19(10), 2921-2947, doi: 10.1007/s10531-010-9798-9

Wittebolle, L., Marzorati, M., Clement, L., Balloi, A., Daffonchio, D., Heylen, K., De Vos, P., Verstraete, W. \& Boon, N., 2009, 'Initial community evenness favours functionality under selective stress', Nature, 458(7238), 623-626, doi: 10.1038/nature07840

Yachi, S. \& Loreau, M., 1999, 'Biodiversity and ecosystem productivity in a fluctuating environment: The insurance hypothesis', Proceedings of the National Academy of Sciences, 96(4), 1463-1468.

Yan, D., Zhao, F. \& Sun, O.J., 2013, 'Assessment of vegetation establishment on tailings dam at an iron ore mining site of suburban Beijing, China, 7 years after reclamation with contrasting site treatment methods', Environmental Management, 52(3), 748-757, https://doi.org/10.1007/ s00267-013-0092-y

Zerbo, I., Bernhardt-Römermann, M., Ouédraogo, O., Hahn, K. \& Thiombiano, A., 2016, 'Effects of climate and land use on herbaceous species richness and vegetation composition in West African savanna ecosystems', Journal of Botany, 2016, 1-11, https://doi.org/10.1155/2016/9523685 


\section{Supplementary material}

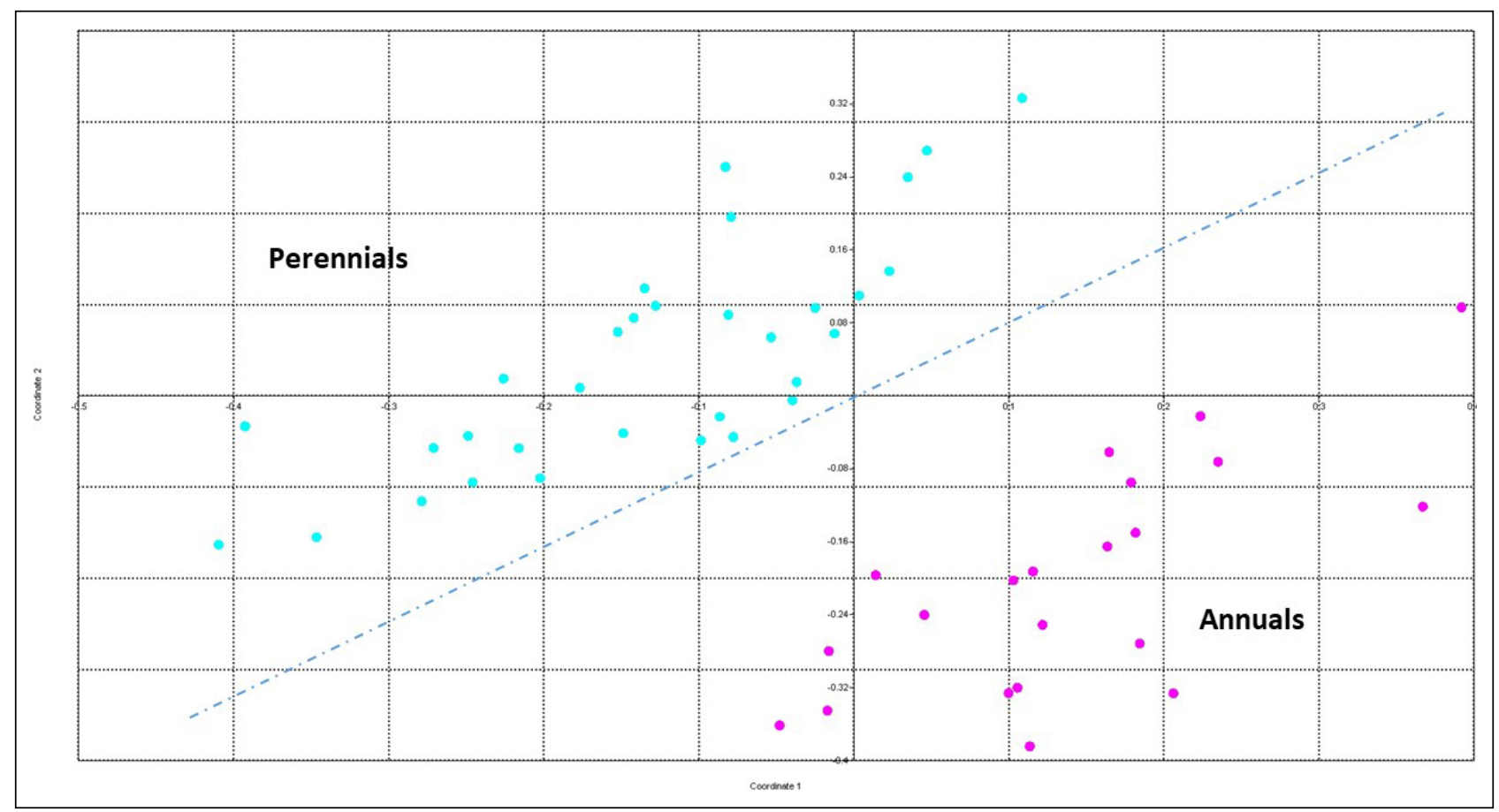

Figure S1. Principal Co-ordinate Analysis (PCoA) scatter diagram of the species-trait matrix revealing a strong clustering based on life history.

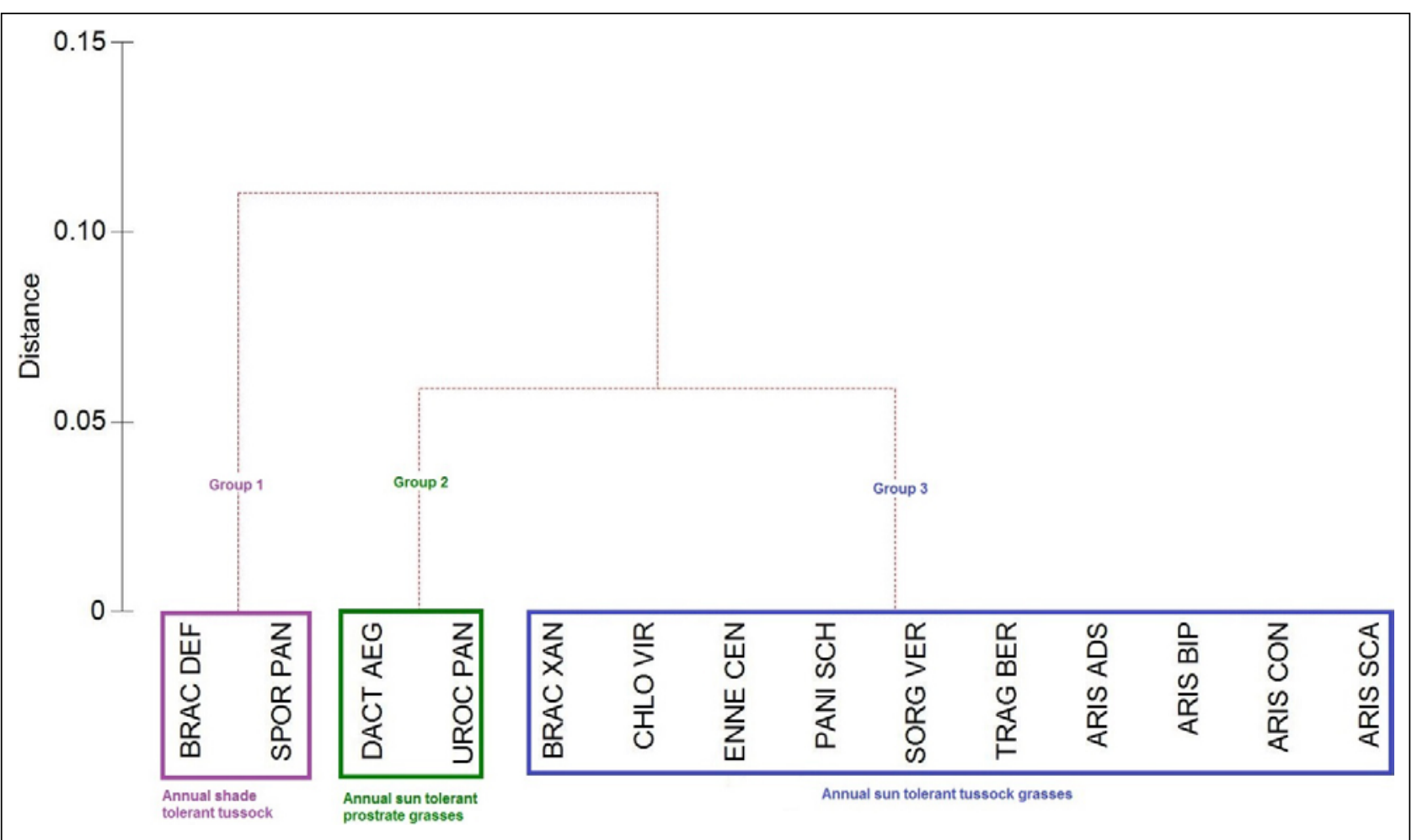

Figure S2. Unweighted Pair Group Method with Arithmetic Mean (UPGMA) based on Gower distance measure indicating annual grass plant functional types (PFTs). 


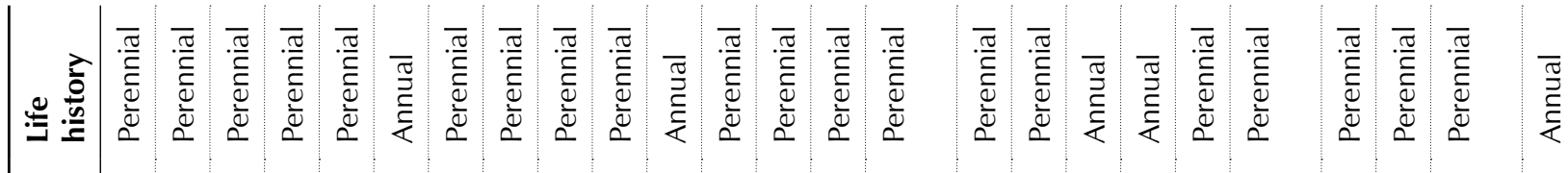

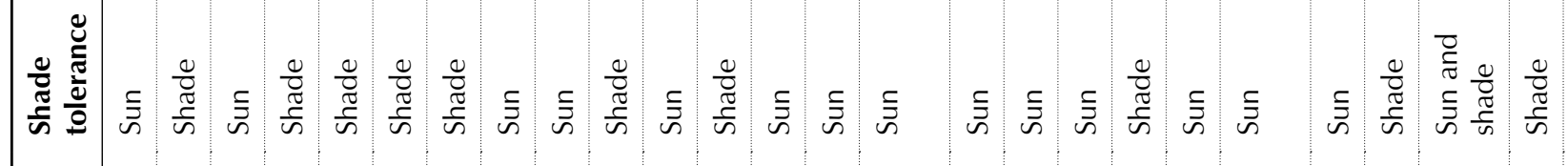

|MIn

金

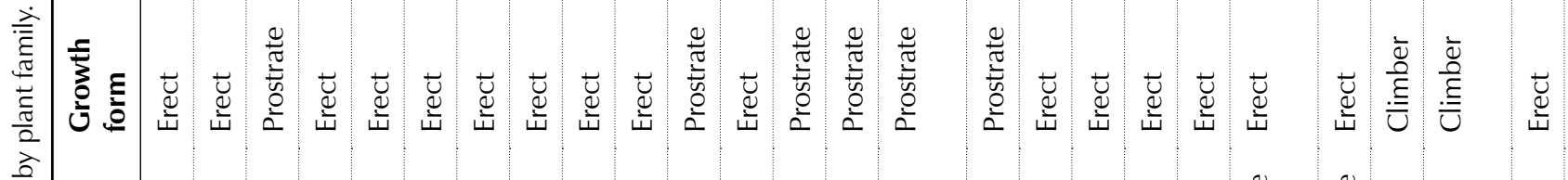

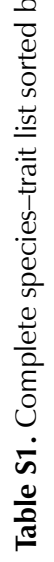

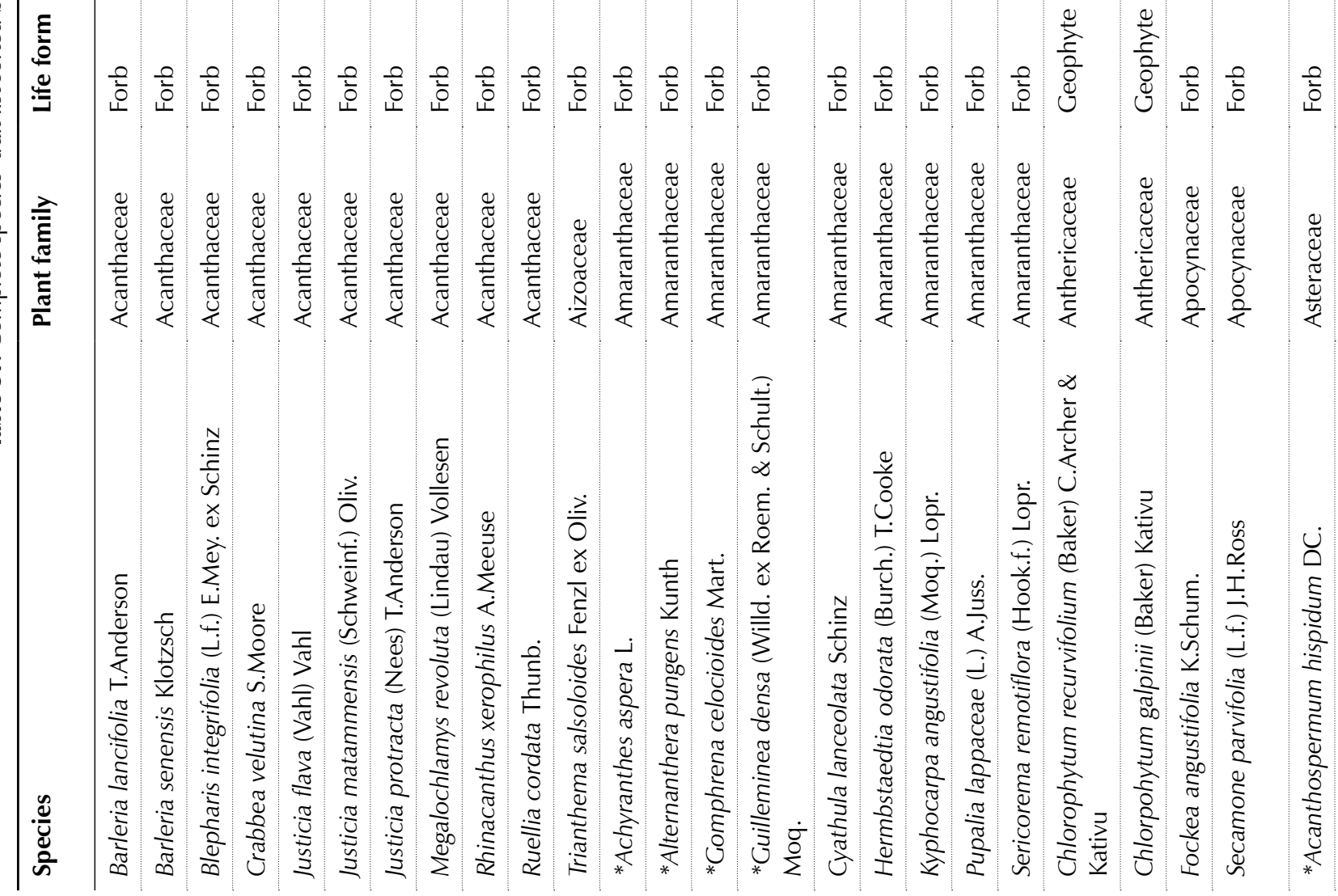




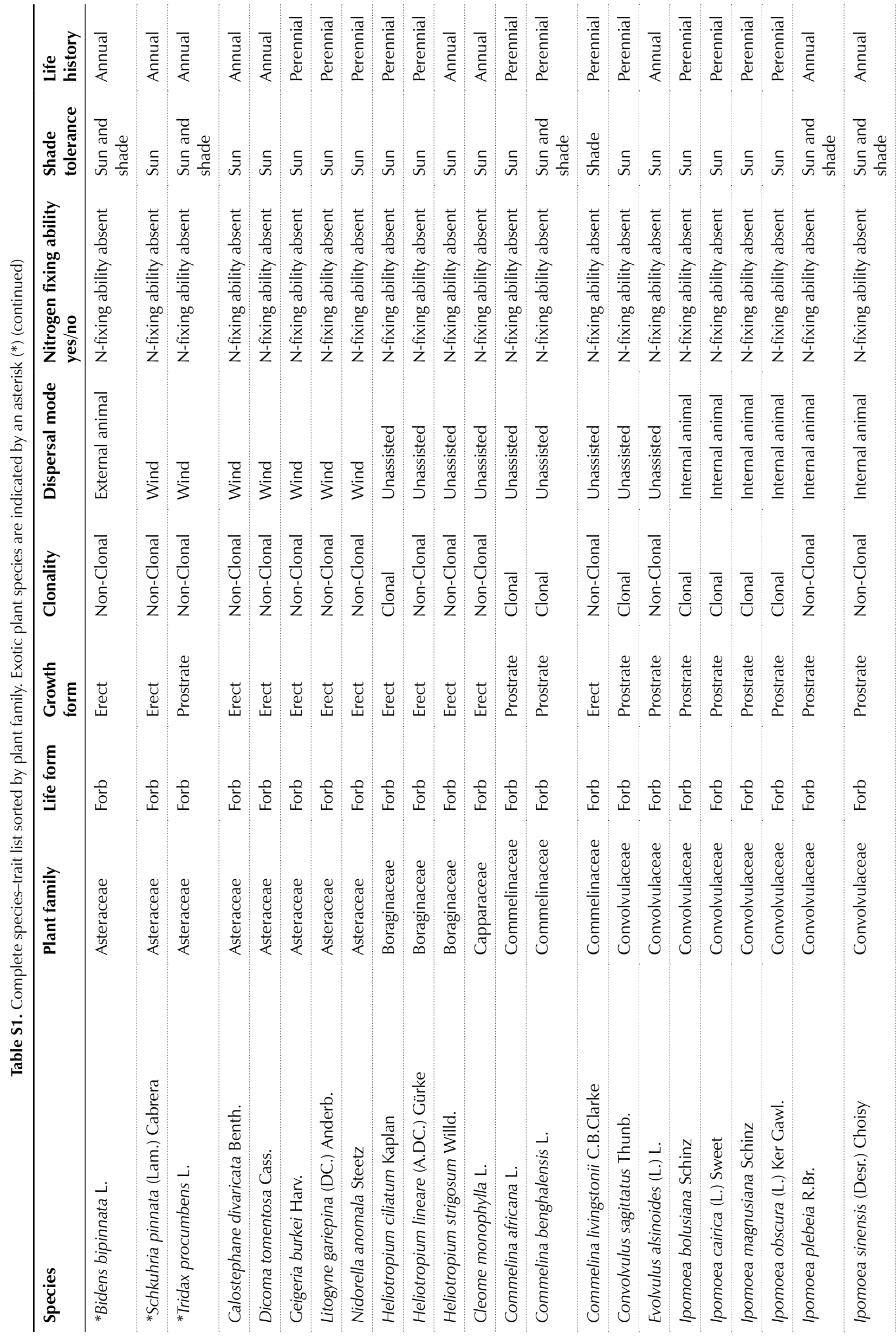




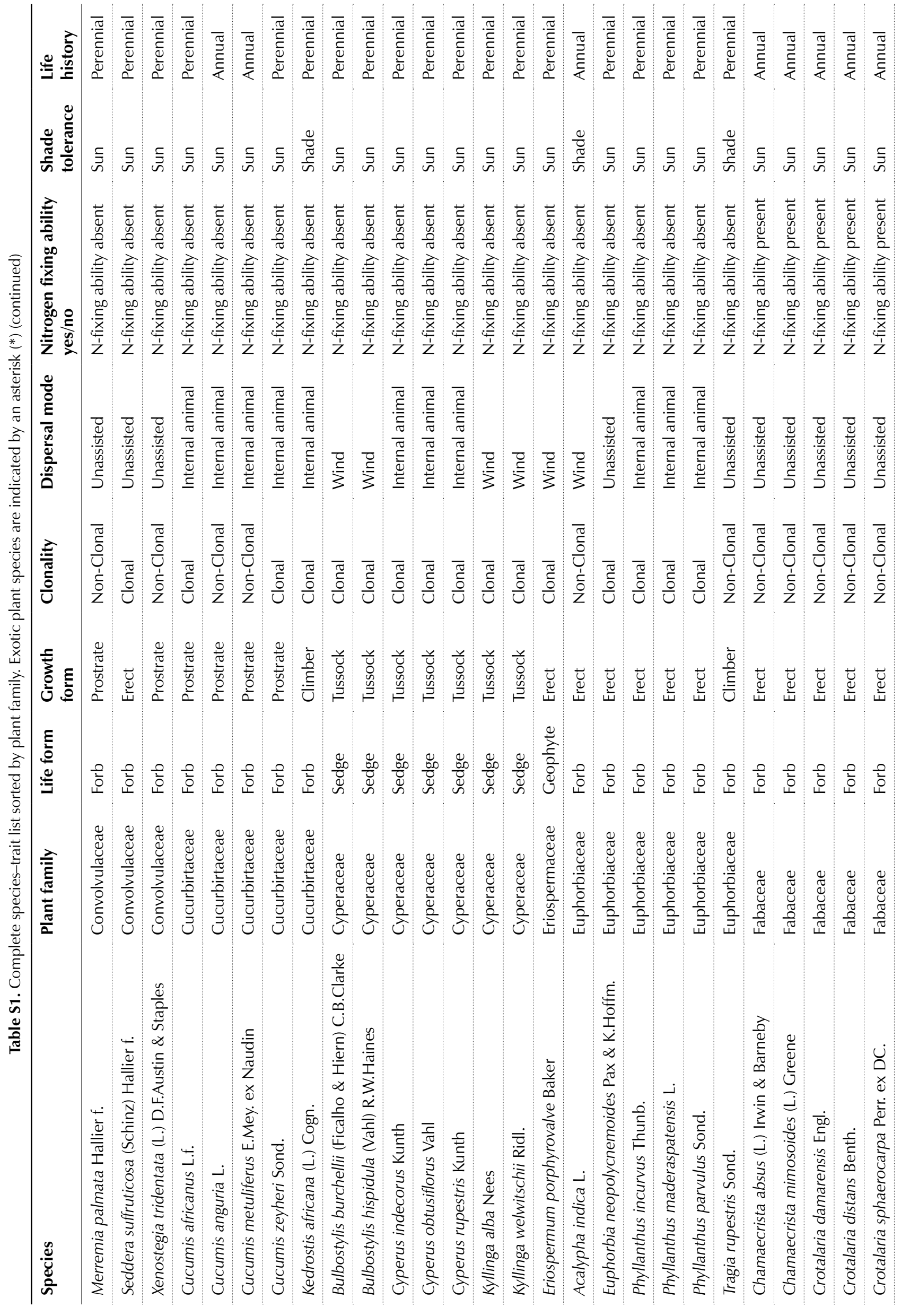




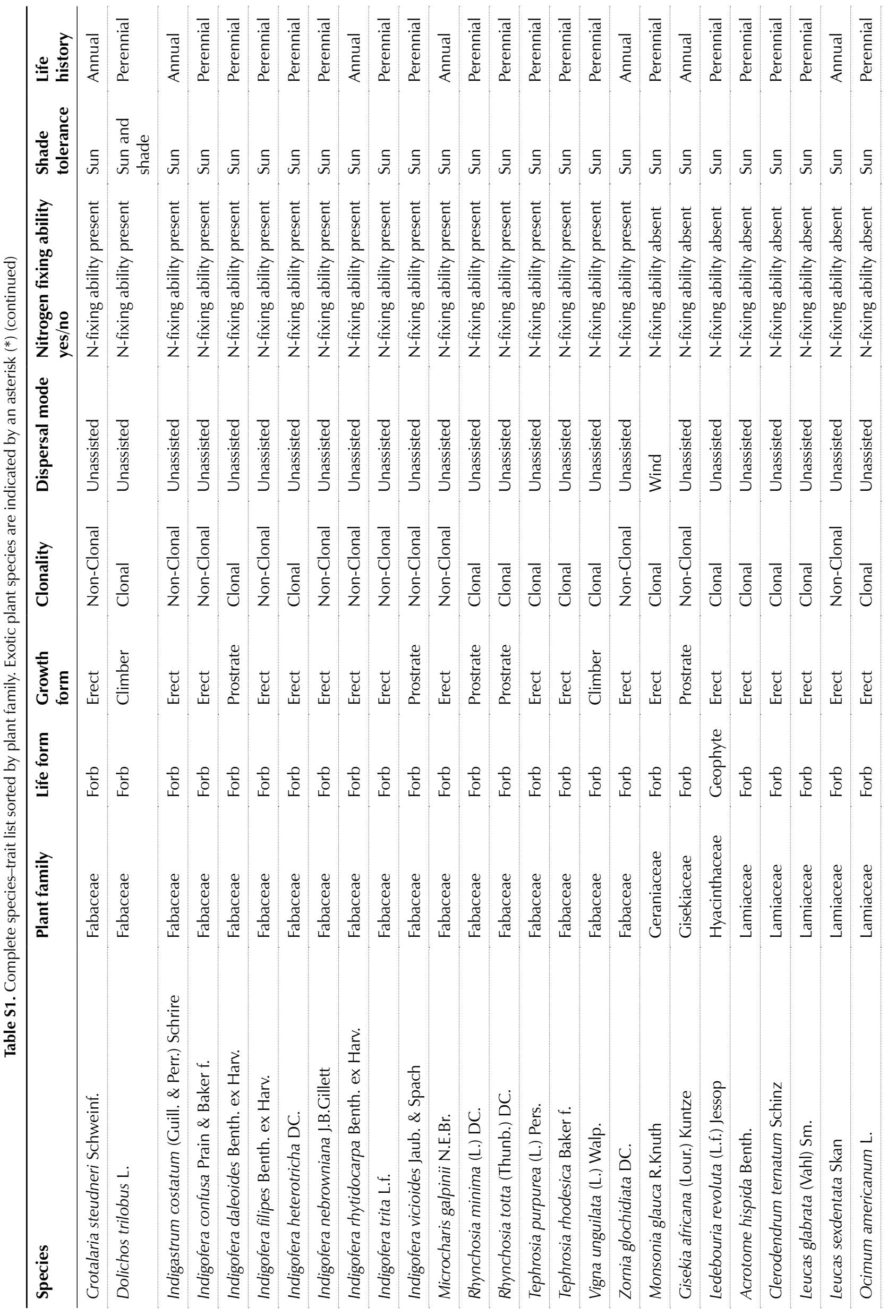




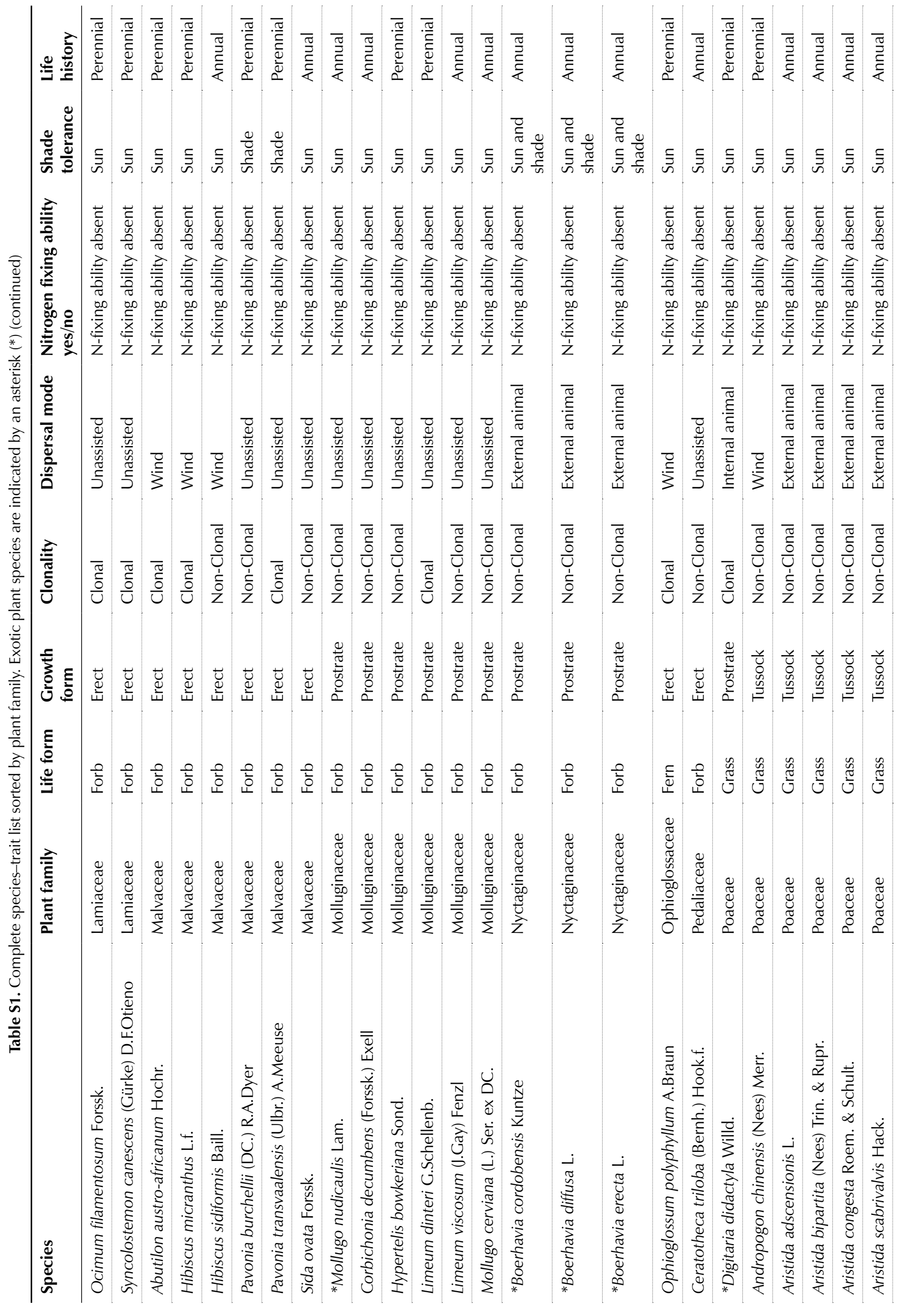




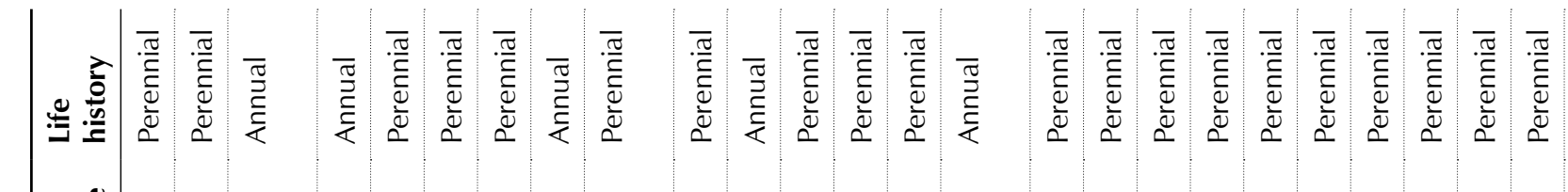

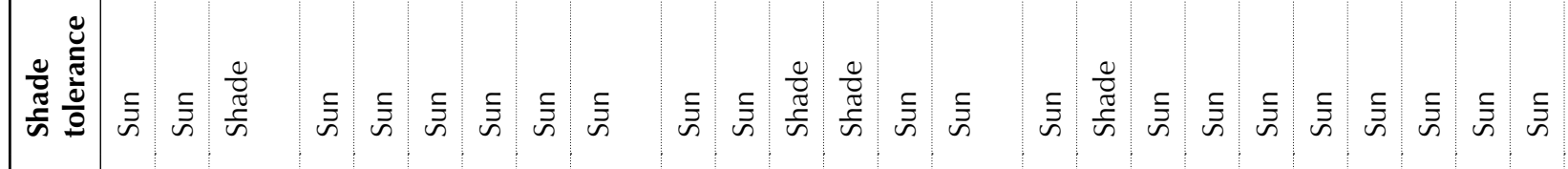

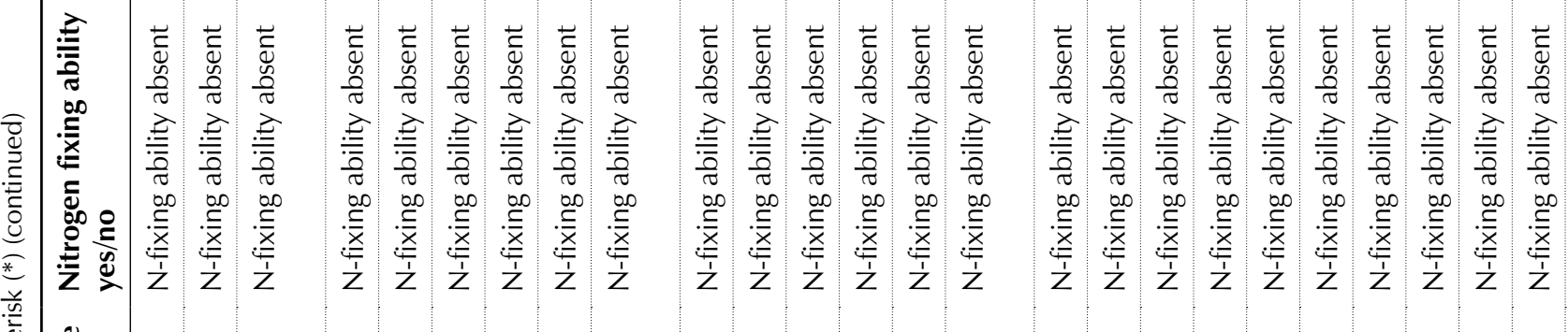
咅

$\begin{array}{lll}\frac{2}{8} & \bar{\varepsilon} \\ \frac{\pi}{0} & \frac{\pi}{2}\end{array}$

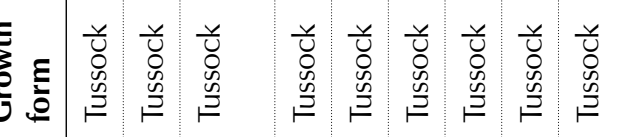

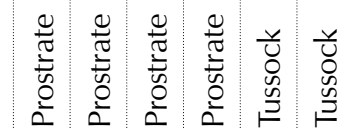

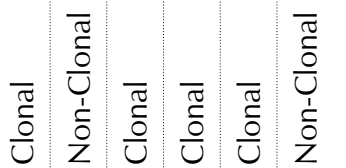

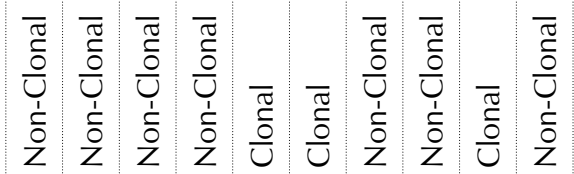

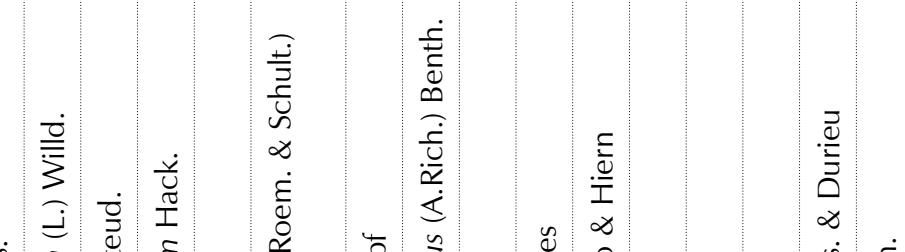

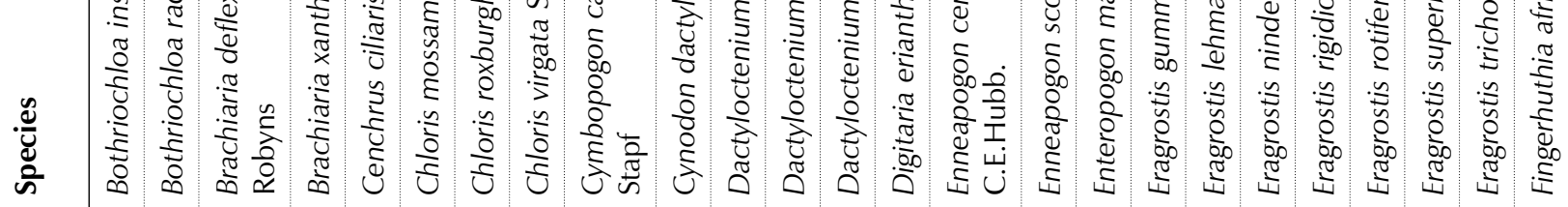









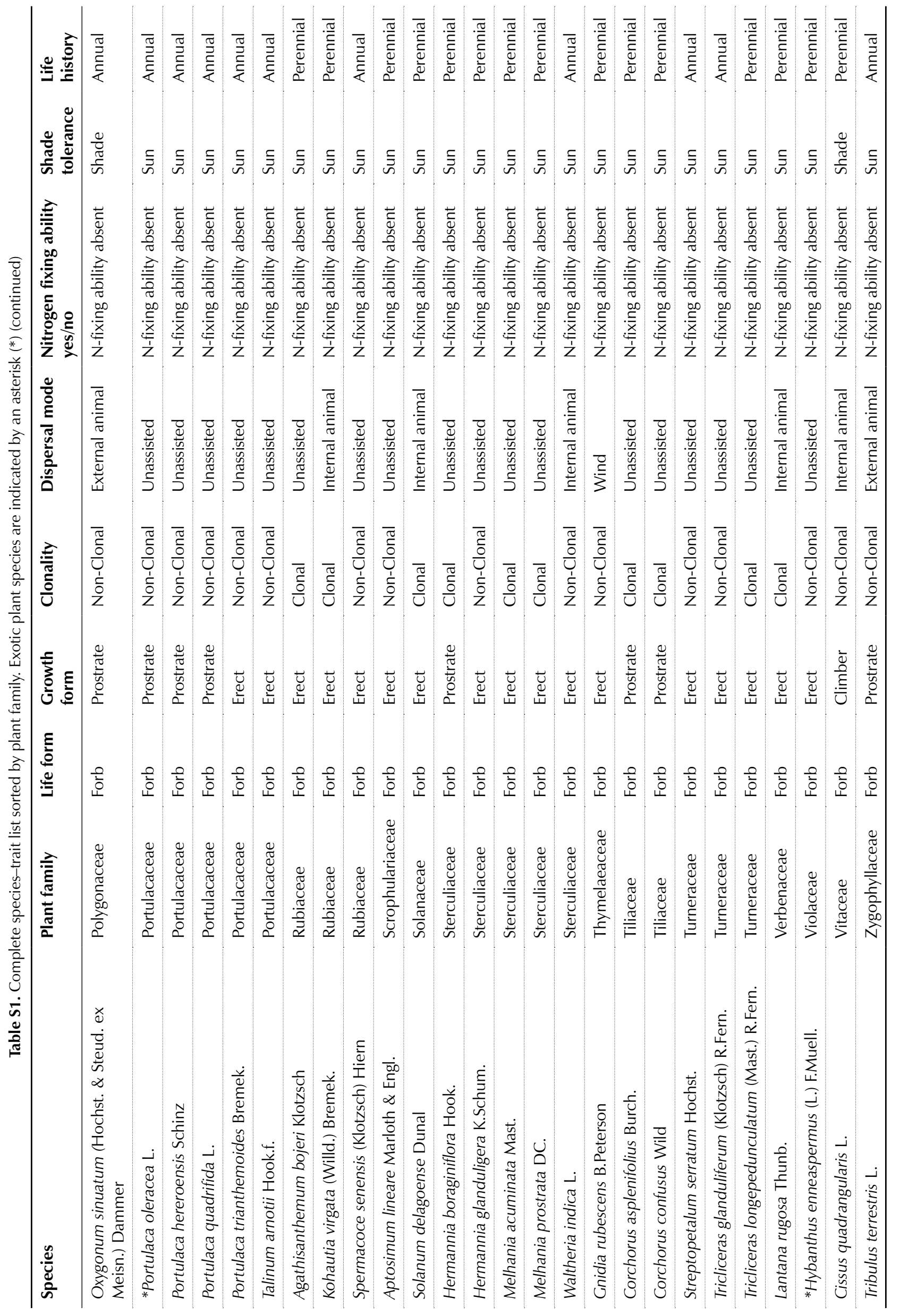




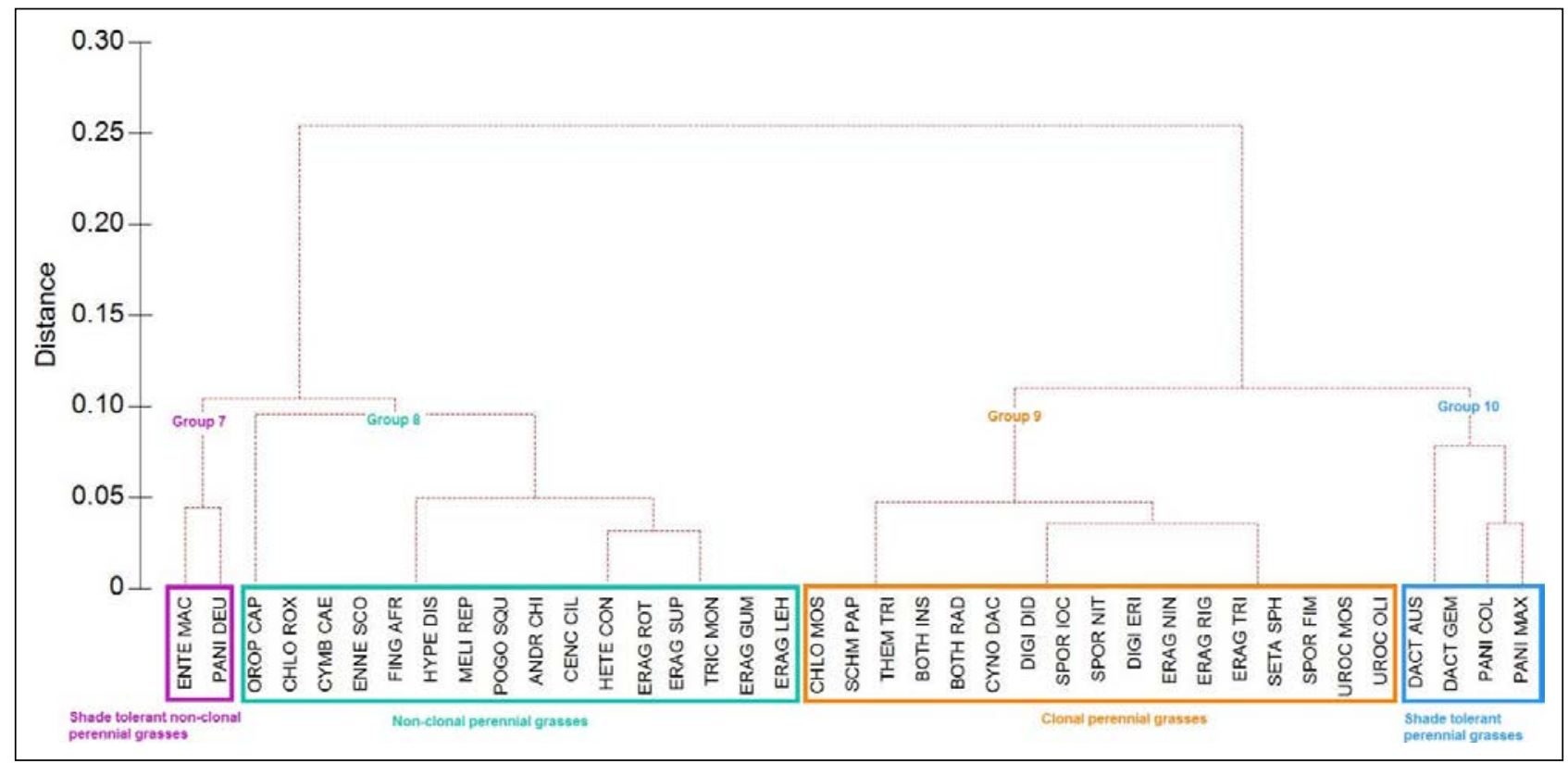

Figure S3. Unweighted Pair Group Method with Arithmetic Mean (UPGMA) based on Gower distance measure indicating perennial grass plant functional types (PFTs).

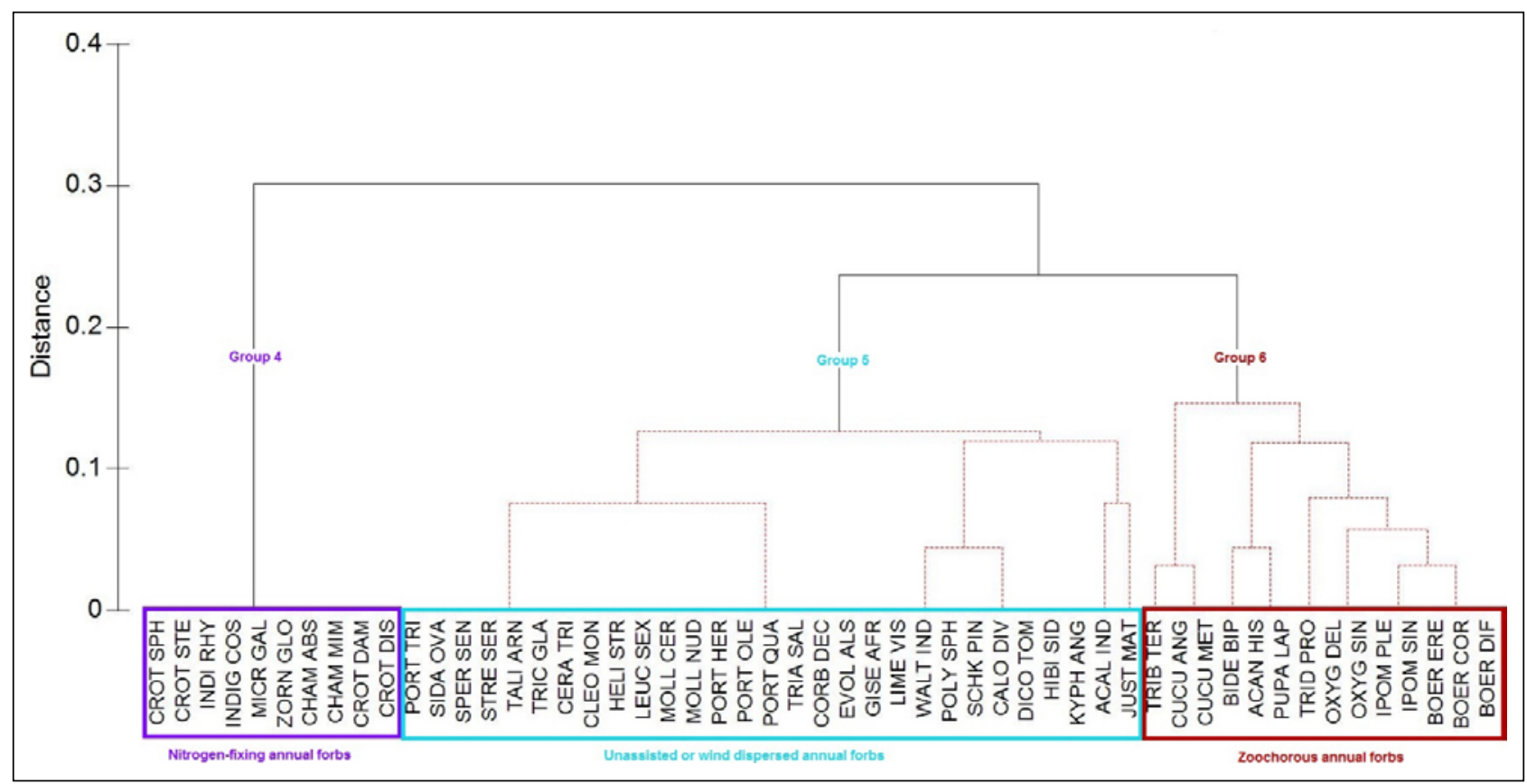

Figure S4. Unweighted Pair Group Method with Arithmetic Mean (UPGMA) based on Gower distance measure indicating annual forb plant functional types (PFTs). 


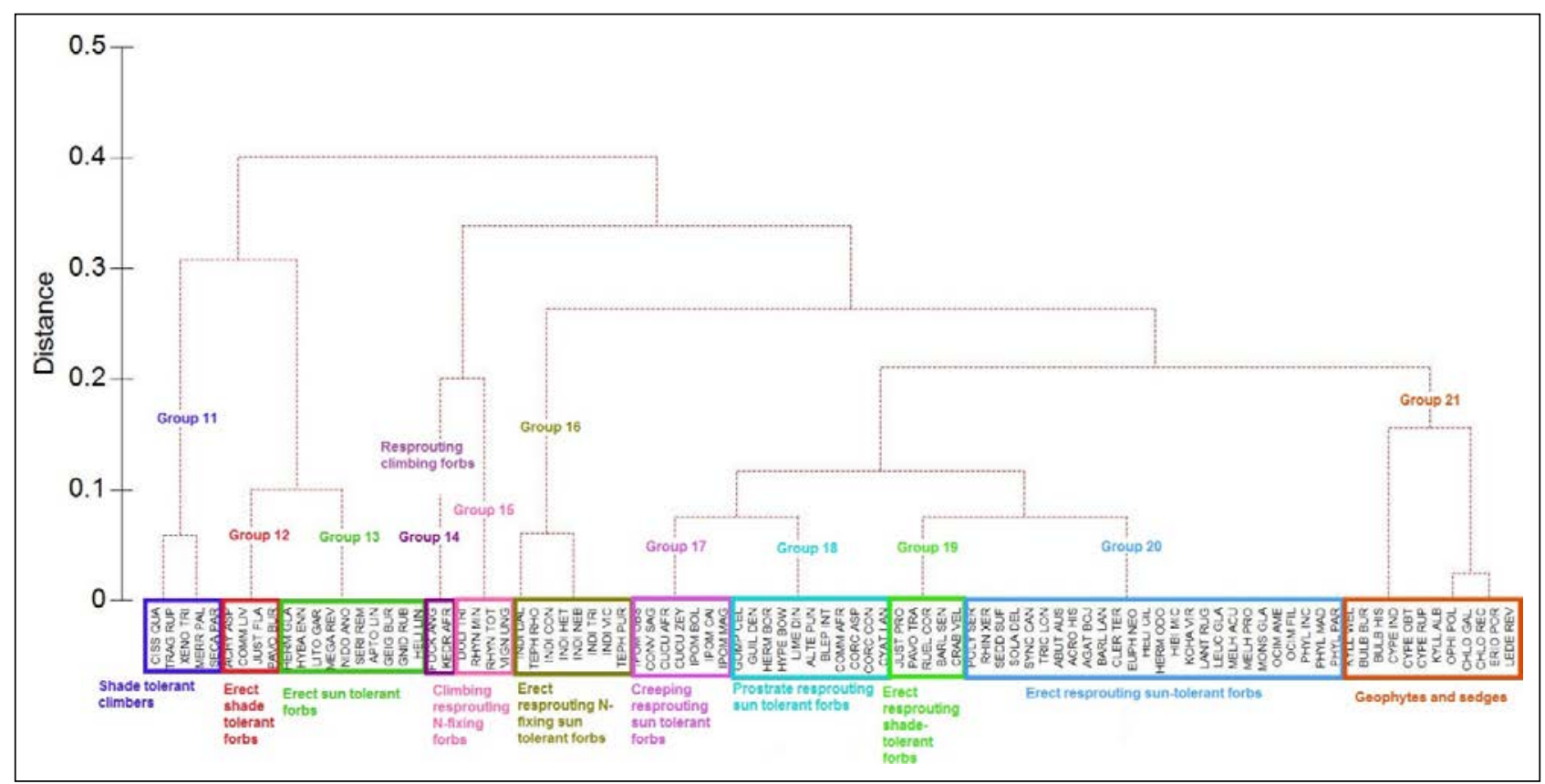

Figure S5. Unweighted Pair Group Method with Arithmetic Mean (UPGMA) based on Gower distance measure indicating perennial forb plant functional types (PFTs). 